\title{
Mimarlık ve Edebiyat İlişkisine Dair Yapılmış Akademik Çalışmaların Bir Sınıflandırması
}

*

\author{
Ayşe Pınar Serin Güner ${ }^{1}$ \\ ORCID: 0000-0003-4043-0219
}

\author{
Hikmet Gökmen² \\ ORCID: 0000-0002-3568-8226
}

Öz

Günümüz teknolojik ve toplumsal gelişmeleri paralelinde, her türden disipliner/disiplinlerarası etkileşimler artarak devam etmektedir. Mimarlı da edebiyat da disipliner üretimlerini toplumsal alanda gerçekleştiren, üretim alanındaki sosyal ortamdan etkilenen disiplinlerdir. Bu çok yönlü ilişki disiplinler arası araştırmalara katkı koyması açısından araştırılmaya açıktır. Makale, mimarlı ve edebiyat arasında her iki alana da etki eden disiplinler arası bilgi aktarımının nasıl gerçekleştirildiği motivasyonuyla, mimarlığın da edebiyatın da mevcut bilgi yelpazesini genişleten disiplinler arası etkileşimlerin akademik araştırmalara etkisini araştırmaya odaklanır. Bu kapsamda 1987 yılından günümüze Yükseköğretim Kurumu (YÖK) Ulusal Tez Merkezi'nin tez arşivinde bulunan, mimarlık ve edebiyat disiplinlerinin ilişkisini irdeleyen, tamamlanmış yüksek lisans/doktora tez çalışmaları farklı açılardan ele alınmaktadır. "Mekân, mimarlik, edebiyat, metin, dil, mimari" gibi anahtar kelimelerle taranan tezler sonucunda, mimarlık ve edebiyat ilişkisinin yalnızca mimarlık ve edebiyat alanlarında değil farklı sosyal disiplinler tarafından da ele alındı̆̆g görülmüştür. Disiplinler arası araştırmalara farklı perspektiflerden katkı koyan, yeni araştırmalara alan açan bu irdeleme makale kapsamında mimarlık disiplini ve mimarlık kavramlarn ile mimarlık alanına sunduğu/sunacă̆ imkânlarla ele alınmaktadır. Makale kapsamında ulaşılan 125 adet tez çalışması mekânı ele alma ve kullanma, mekânın anlamın yeniden üretme potansiyelleriyle tartışılırken, bu iki alanın bilgisinin hangi edebi eserler, hangi edebiyatçllar, edebiyat alanında hangi kavramlarla ele alındığının değerlendirmesini de ortaya koymayı amaçlamaktadır.

Anahtar Kelimeler: Mimarlık, Edebiyat, Mekân, Disiplinlerarası Etkileşim, Ulusal Tezler

\footnotetext{
${ }^{1}$ Yüksek Lisans, Dokuz Eylül Üniversitesi, E-mail: pnrserin@gmail.com

${ }^{2}$ Doç. Dr., Dokuz Eylül Üniversitesi, E-mail: hikmet.gokmen@deu.edu.tr

idealkent (c) Kent Araştırmaları Dergisi (Journal of Urban Studies) 


\title{
A Classification of Academic Studies on the Relationship between Architecture and Literature
}

\author{
Ayşe Pınar Serin Güner ${ }^{3}$ \\ ORCID: 0000-0003-4043-0219
}

\author{
Hikmet Gökmen ${ }^{4}$ \\ ORCID: 0000-0002-3568-8226
}

\begin{abstract}
Today's technological and social developments, all kinds of disciplinary / interdisciplinary interactions increasingly continue. This relationship is open to exploration in terms of contributing to interdisciplinary research. The study focuses on researching the effects of interdisciplinary interactions on academic studies. In this context, completed master's/doctoral thesis studies, which are in the thesis archive of the National Thesis Center of the Higher Education Institution since 1987, are included. As a result of the theses scanned with keywords as "space, architecture, literature, text, language, architecture" it is seen that the relationship between architecture and literature is not only dealt with in the fields of architecture and literature, but also by different social disciplines. This examination, which contributes to interdisciplinary research from different perspectives and opens up new researches, is handled within the scope of the study with the architectural discipline and the concepts of architecture and the possibilities it offers to the field of architecture. A total number of 125 thesis reached within the scope of the article are discussed with the potential of handling. It also aims to reveal the evaluation of how the knowledge of these two fields are handled with which literary works, which literati and which concepts in the field of literature.
\end{abstract}

Keywords: Architecture, Literature, Place, Interdisciplinary Interaction, National Theses

\footnotetext{
${ }^{3}$ Master, Dokuz Eylül University, E-mail: pnrserin@gmail.com

${ }^{4}$ Assoc. Prof., Dokuz Eylül University, E-mail: hikmet.gokmen@deu.edu.tr

idealkent (c) Kent Araştırmaları Dergisi (Journal of Urban Studies)

http://idealkentdergisi.com

Geliş Tarihi Received Date: 20.11.2020 Kabul Tarihi Accepted Date: 30.12.2020
} 


\section{Giriş}

Mimarlık ve edebiyat toplumsallıkla ortaya çıan, var olan ve sürdürülen sanatsal alanlardır. Toplumsal ortamda var olan tüm gerçeklikler, edebi eserlere ve mimarlık alanına doğrudan yansır. Edebiyat ve mimarlık ilk bakışta sosyoloji, psikoloji, felsefe ve tarih gibi sosyal bilimlere ait diğer disiplinler kadar doğrudan ilişkilendirilememektedir. Oysaki mimarlık da edebiyat alanı da toplumsal ortamın bir parçası olarak kendi bağlamlarında ilişki içerisindedir. Edebi eserlerin içerisinde tasvir edilen mekânsal anlatılar, gerçek/kurgusal mekâna ait yazılı bilgiler aktarır. Edebi eserde anlatılmak istenen duygu ve düşüncenin daha iyi aktarılması, olay örgüsünün okuyucunun zihninde daha belirgin imgeler yaratması ve eserde yer alan karakterlerinin psikolojik tasvirlerinin daha detaylı yapılabilmesi için her zaman mekânsal anlatılara ihtiyaç duyulmaktadır. Mimari perspektifte ise mimarlık pratiği mimari teori, mimarlık kuramı ve mimarlık tarihi gibi araştırma alanları yazılı anlatıma, metne gereksinim duyar. Bir mimari yapı, tasarımından inşa edilmesine ve hatta deneyimlenme sürecinde bile sayısız yazılı ifadeye gereksinim duyar. Günümüzde mimari dille inşa edilen birçok mimari yapı hakkında mimarlık ortamına ve mimarlık bilgisine katkı koyan yazılar yazılmaktadir.

Mimarlık ve edebiyat arasında toplumsal dinamiklere bağlı olarak gerçekleşen disiplinler arası etkileşim toplum bilimlerinde yapılmış birçok çalışmaya yansımıştır. Makale, mimarlık ve edebiyat ilişkisine disiplinler arası ortamda gerçekleştirdikleri iletişimi odağına alarak bakar. Bu disiplinler arası etkileşimi sağlayan temel unsur her iki disiplinin kullandığı dil ve metindir. Makale kapsamında mimarlık ve edebiyat ilişkisi, mimarlık ve edebiyat arakesitinde gerçekleştirilmiş lisansüstü tez çalışmaları perspektifinden irdelenmektedir. Mimarlık ve edebiyat disiplinlerinin birlikteliğinin lisansüstü tez çalışmaları boyutuyla ele alındığı makalenin kavramsal altyapısı ise her iki alanın toplumsallığı, dili ve yazıyı kullanma durumları ve dille kurdukları iletişim boyutuyla ele alınmaktadır.

Mimarlık ve edebiyat meslek pratiklerini farklı disipliner diller kullanarak sürdürürler. Makalede mimarlık ve edebiyatın ilişkisinin temelinin dil unsuru ile başladığı düşünülmektedir. Mimarlık inşai bir üretim şekli olarak düşünce ve üretiminde öncelikli olarak yarattığı imajlara ve fiziksel gerçekliğe dayalı mimari dili kullanırken; edebiyat, edebi eserlerinde yazılı üretimle gerçekleştirdiği edebi dili kullanır. Farklı dilleri kullanan bu iki ortamda edebi- 
yatın edebi dili içerisindeki mekâna dayalı bilginin, mimarlık ortamında üretilen lisansüstü araştırmalara ne şekilde yansıdığı tartışılmaktadır. Benzer şekilde her ne kadar edebi dili kullanmasa da mimarlık disiplininin yazı diline dayalı unsurları bir araç olarak kullanarak kendi disiplininin mevcut bilgi çerçevesini hangi kavramlarla akademik perspektifte ele aldığı araştırılmaktadır.

Yazınsal metinlerin öğretici (didactic) ve esinlenici (inspirational) olma durumu mimarlık bilgisine farklı açlardan katkı koyar. Yazınsal metinlerden yapılan bu çıkarımların mimari üretimi doğrudan besleme özelliği olup mimarlık alanına ve mekâna dair gerçekleştirilecek araştırmalara kaynak oluşturacağı düşünülmektedir (Çağlar, Ultav ve Boyacıŏglu, 2013; s.62-63). Mimarlık disiplini çerçevesinden ve mimari bakış açısıyla gerçekleştirilen bu araştırmayla, öncelikli hedef mimarlık ve edebiyat arasındaki diyalektik durumların mimarlık bilgisine katkı koyması ve yeni alanlar açmasıdır.

\section{Disiplinlerarası Toplumsal Bir Üretim Alanı Olarak Mimarlık}

Mimarlık disiplini yalnızca fiziksel mekân inşa etmek üzerine bir meslek pratiği değildir. Mimarlık, doğası gereği mekânı üretirken mekânın kullanıcısı ve onun çevreyle ilişkisini göz önünde bulundurmak, kullanıcının hem fiziksel ihtiyaç ve özelliklerine hem de sosyal ve psikolojik ihtiyaçlarına/aktivitelerine uygun yaşam alanları tasarlamak zorundadır. Mekânın üretimine bir veri olarak dâhil edilen bu fiziksel, sosyal, psikolojik parametreler, mimarlığın toplumsal bir üretim olmasının ve bu durumun mimarlığı disiplinler arası bir bilgi üretim alanı haline getirmesinin doğal bir sonucudur.

Disiplinler arası gerçekleşen her türden toplumsal üretimler doğası gereği birden fazla alanın ortak katkısı ile yürütülen, çoklu bakışa sahip bir bilgi üretim biçimidir. Disiplinler arası gerçekleşen bu etkileşimli üretim sürecinde her disiplin kendi alanının bakış açısını yansıtarak bu çok bakışlı bilgi üretimine katkı koyar.

Toplumsal ve sosyal ilişkiler, gündelik hayat aktiviteleri bir mekân içerisinde gerçekleşir. Mekân gereksinimi olan toplumsal pratikler mekânı bir etkileşim ve deneyimleme alanı haline getirir. Mekânı üreten, mekânsal ilişkileri kurgulayan mimarlık, mekânın toplumsal boyutuyla gündelik hayatın ve gündelik hayata etki eden tüm sistemlerin bir parçasıdır.

Kentsel mekânı kurgulayan/inşa eden mimarlık ve mekân bilgisi de toplumsal alana temas eden birçok disiplinin araştırma ve çalışma alanına dâhil olmaktadır. Mimarlığın doğası gereği insanı ve insana dair tüm durum- 
ları/faaliyetleri önceleyen ve kapsayan yapısı, mimarlık disiplininde gerçekleştirilen kuramsal çalışmalara ve mesleki pratiklere yansımaktadır. Fransız sosyolog/eleştirmen/felsefeci Henri Lefebvre, 1974 yılında yayınladığı "Production de l'espace -The Production of Space" (Mekânın Üretimi) adlı eserinde mimarlığın çok yönlü toplumsallığına işaret eder. Kendinden önceki düşünürlerin mekâna bakışlarından farklı olarak mekânın toplumsal yönünü vurgulayan Lefebvre mekânı sosyal yaşamın hem aracı hem de sonucu olarak görür. Bu görüşe göre mekân, toplumsal bir üründür ve toplumsal alana ait her üretim biçimi mekânı yeniden üretmektedir. Mekân, bu toplumsal yönüyle hem fiziksel bir üretim hem de gündelik yaşam faaliyetleri ve deneyimleri içeren çok sayıda fiziksel olan/olmayan katmanları içeren disiplinler arası yaklaşımla ele alınması gereken bir olgudur. Mimarlık aracılığıyla inşa edilen fiziksel çevre de deneyimlenerek, kullanılarak, hatırlanarak ve yaşanarak sürekli olarak yeniden üretilir (Lefebvre, 1974: 2014).

Lefebvre'nin görüşüne benzer şekilde mimarlık tarihçisi ve kuramcısı Uğur Tanyeli kendisiyle yapılan “Uğur Tanyeli ile Söyleşi: Toplumsallık Üretim Biçimi Olarak Mimarlı" adlı söyleşide mimarlığın bir "toplumsallk üretme pratiği" olduğunu ve toplumsallık üreten her pratiğin kendi alanının özerk olma durumunu bozduğunu, alanın sınırlarını problemli hale getirip tartışmaya açtı̆ını öne sürer. Toplumsallık üreten her pratiğin kendi alanının var olan sınırların genişletmeye zorunlu olduğunu ve mimarlığın da bu disiplinler arası ortamdaki kaostan faydalanması gerektiğini savunur. Mimarlığı herkes tarafından kolayca anlaşılır bir formun içerisine hapsetmek yerine onu her defasında sinırları olmayan bir dünyada yeniden üretilen bir virtüellik olarak görür. Tanyeli'nin sadece mimarlık alanına indirgenemeyecek kadar somutlaştırarak ele aldığı toplumsallık meselesi "kültür dünyasına" da önemli ölçüde yaslanır. Tanyeli bu bağlamda toplumsallığ1 "en geniş anlamda fiziksel çeore üretimi alanından bakıp, aslında toplumsalliğı, onun mekânlardaki, düşüncelerdeki, pratiklerdeki, estetik duyuşlardaki tezahürlerini" anlamaya çalışmak olarak görür (Karadeniz ve diğ., 2016).

\section{Mimarlık ve Edebiyatta “Dil”}

"Dil varlğı̆ evidir" Heidegger, 1999; s.5

"Insanlarn düşündüklerini ve duyduklarmı bildirmek için kelimeler veya işaretlerle yaptıkları anlaşma, lisan" anlamına gelen dil, farklı alanlarda farklı anlamlar 
taşıyan çok yönlü bir olgudur. İletişimin çoğu zaman ön koşulu olan dil, temelinde anlaşma ve anlama amacı olan bir anlatım ve ortak iletişim aracıdır. "Bir çağa, bir gruba, bir yazara özgü söz dağarcı̆̆ı ve söz dizimi" de olan dil aynı zamanda bir mesleki disipline veya üretim biçimine ait ortaklık anlamına da gelmektedir. Meslek gruplarının, üretim biçimlerinin/araçlarının, uzmanlık alanlarının bir dili olabileceği gibi bu alanlarda üretilen nesnelerin de kendine özgü yapıları/dilleri olabilmektedir (TDK Sözlük, 2020).

Fransiz dilbilimci André Martinet dili "insanın kendi bilgi ve deneylerini, bir anlamsal kapsamı ve bir ses karşılı̆̆ olan birliklerle her toplumda bir başka biçimde açıkladı̆̆ı bir bildirişme aracı" olarak tanımlar (Martinet, 1985). Dilin toplumsal özelliğine vurgu yapan Martinet'in görüşüne paralel olarak Aksan da dili "düşünce, duygu ve isteklerin, bir toplumda ses ve anlam yönünden ortak olan ögeler ve kurallardan yararlanılarak başkalarına aktarılmasinı sağlayan, çok yönlü, çok gelişmiş bir dizge" olarak açılar (Aksan, 2007; s.55). Dil, bu toplumsal yönüyle toplumsal dinamiklerle birlikte farklı kalıplarla var olur ve aralarında mimarlık ve edebiyatın da yer aldığı toplumsal disiplinlerle ilişki içerisindedir.

Mimarlık, sahip olduğu temel unsurlar ve ifade biçimleriyle kendine ait bir dilsel sistemi olan, aynı zamanda kendi söylem ve gerçekliğini ifade etmede yazı dilini kullanan bir alandır. Geçmişten günümüze mimarlık bilgi alanını tanımlayan yazılı, sözel ve inşa etmeye dayalı tüm süreçler mimarlık disiplininin bütüncül dilsel sistemini oluşturan unsurlardır.

Gürhan Tümer mimarlığın dille olan ilişkisini açıklarken mimari yapının kurulumunda mimarın dille, sanatla ve doğayla ilişki kurmasının zorunlu olduğunu belirtir. Tümer'e göre mimarlık ve dil ilişkisinin bir geçmişi ve aşamaları vardır. Mimar, yapısını tasarlamadan önce yazılı ve sözlü araştırmalar yapar ve bu süreçlerin bir kısmını dilsel olarak yürütür, dilden yoğun olarak yararlanır. Yapının inşa aşamalarında yine sözlü ve yazılı olarak meslek pratiğini yürüten aktörlerle dil aracılığıyla ilişki kurulması gereklidir. Bunların ötesinde mimarın bütün sanat dallarından faydalanması, estetik bilincinin gelişmesi için yazın sanatıyla, dille ilişki kurması gereklidir (Tümer, 1982).

Edebiyat alanı da toplumsal bir sanat alanı olarak eserlerini toplumsal ortamdan beslenerek üretir. Edebiyat alanı, sanatsal üretimini gerçekleştirirken edebi dili kullanır. Edebi eserler yazı/metin yoluyla üretilir ve bu bakımdan yazı dili edebiyatın var olması için temel araçıır. Edebiyat alanında dilin sistematik bir dizgeler bütünü olarak anlamlı bir şekilde bir araya gelmesi yazıyı, yazının edebi bir anlatımla belli kuram/yöntem/türlere ayrılarak özelleşmesi ise edebi eseri var etmiştir. Edebiyatta kullanılan edebi dil, hem edebi 
eserin var olmasını sağlayan bir araç hem de edebiyatın amacıdır. Çünkü edebiyat okuyucuyla iletişim kurma hedefini kullandığı edebi dil aracilığıyla gerçekleştirir. Edebiyatçının kullandığı edebi dil araçsallaşarak edebi esere dönüşür.

Mimarlık alanının da edebiyatın da kullandığı yazılı/sözlü/görsel/teknik dil sayesinde gerek disipliner gerekse disiplinler arası çeşitli iletişim ve etkileşim ortamları oluşur. Her iki alanda da dil toplumsallığın, alanın bilgi üretiminin ve iletişim kurabilmenin aracı durumundadır. Dili kendi mesleki bilgisi çerçevesinde kullanan iki alanın birbiri içerisinde ne şekilde var olduğu, makalenin ana motivasyonlarından biridir. Mimarlik ve edebiyat arasında, her iki disiplin özelinde ve birlikteliğinde yapılan araştırma ve çalışmaların ortaya konulması mimarlık için de edebiyat için de yeni perspektifler sunma potansiyeli barındırmaktadır. Mimarlık ve edebiyat ilişkisinin çözümlenebilmesi için her iki alanın dille ve yazıyla kurduğu ilişki biçimlerinin irdelenmesi ve bu araştırma için bir sorgulama biçimine dönüşebilmesi alanın bilgisi açısından faydalıdır.

\section{Mimarlık ve Yazı İlişkisi}

Yazıdan (metin) ve metnin mimarlıkla olan bağından söz etmeden evvel dilin metne dönüşme sürecinin anlaşılması gerekir. İnsanların birbiriyle sözlü, yazılı olarak veya imajlar aracılığıyla iletişim kurmalarını, duygu ve düşüncelerini ifade etmeleri sağlayan göstergeler bütünü olarak dil içerisinde yaşadığ1mız dünyayı anlamlandırmada, duygu, düşünce ve bilgilerin aktarımda ve iletişim kurmada bize yardımcı olur.

Yapısal dilbilimin kurucusu Saussure, dil ve yazı arasındaki ilişkiyi betimlerken sözlü dil ile yazı dilinin birbirinden ayrıldığını öne sürer. Saussure'a göre "Dil ve yazı birbirinden ayr iki gösterge sistemidir ve yazının var oluş nedeni dili göstermektir." (Saussure, 1985). Yazı, kendi bütünsel göstergeleri olan sistematik bir iletişim kanalı olarak dilin içerisinden doğmuştur. Dilbilimin önemli yöntemlerinden biri olan "göstergebilim" (semiyotik/semiyoloji), gösteren ve gösterilenden oluşan bir kavramdır. Çağdaş göstergebilimin temsilcilerinden de olan Saussure "Genel Dilbilim Dersleri" adlı eserinde göstergebilimi, "göstergelerin toplum yaşamı içindeki durumunu inceleyen bir bilim dalı" olarak tanımlar (Saussure, 1985: s.18). Bu sebeple iletişimin doğru şekilde gerçekleşebilmesi için gündelik yaşamda her an karşılaştığımız göstergelerin doğru anlaşılması önemlidir. Göstergebilimin önemli temsilcilerinden Roland Barthes ise göstergebilimde dil üzerinde durur ve göstergelerin dil ile 
gerçeklik kazandığını öne sürer. Barthes'a göre göstergebilimde dil baştan çıkarandır ve sadece yazıda değil; her yerdedir (Barthes, 1979). Barthes bu tanımıyla Saussure'nin göstergeye yüklediği anlamın ve bu anlamın sinırlarının gelişmesini sağlamıştır (Bircan, 2015).

Göstergebilim temelde gösteren ve gösterilen arasında gerçekleşen iletişime dayalı sistematik süreçler bütünüdür. Dilbilim alanından ortaya çıkan ve disiplinler arası çalışmalara konu olan göstergebilim toplumsal yönüyle dilbilimi ile diğer disiplinler arasındaki sınırları genişletir, disiplinler arası karmaşık ilişkilerin çözümlenmesine yarayan bir araç olarak karşımıza çıkar (Kıran, 1990). İnsanlar geçmişten günümüze çeşitli göstergelere bağlı olarak gündelik faaliyetlerini gerçekleştirmiştir. Dilsel bir anlaşma/iletişim biçimi olan göstergeler yazılı ve sözlü oldukları gibi işaretlere, sembollere, hareketlere ve seslere dayalı da olabilirler. Bir göstergede gösteren ile gösterilen arasındaki ilişkinin kurulması sürecine "anlamlama" denmektedir (Çağlar, 2012).

Mimarlık ve edebiyatın bir diğer kesişim noktası her iki disiplinin de iletişim kurma sürecinde göstergebilimden faydalanmalarıdır. Göstergebilim birçok mimari düşünceye etki etmekte ve mimarlık alanının konularına dâhil olmaktadır. Umberto Eco'ya (1979) göre mimarlık insan topluluklarının isteklerini karşılamak ve hayatlarına belirli bir yön vermek üzere gerçekleştirilen bir kitle iletişim aracıdır. Ecónun bu düşüncesine göre mimari fiziksel varoluşuyla ve zihinsel kavranışıyla göstergelerle ilişkilidir. Mimari yapı mevcut varlığının yanında iletişim/mesaj/anlam taşıma görevi de gördüğü için göstergebilimle yakından ilişki içerisindedir.

Mekânsal inşa pratiği olan mimarlık eylemi ve mimarlık disiplininin mesleki bilgisi süreç içerisinde kendini yazı ile ifade etmeye gereksinim duymuştur. Mimarlık disiplini hakkında günümüze ulaşan, bilinen en eski yazılı metinler Vitruvius'un dilimize "Mimarlı Üzerine On Kitap" olarak çevrilen ve MÖ 25 yılında yazıldığı tahmin edilen "De Architectura" adlı eseridir (Vitruvius, 2005). Vitruvius'tan önce mimarlık ve mekânsal inşa eylemine yönelik metinsel ifadeler ağırlıklı olarak mimarlığın kendi bilgi alanı tarafından üretilmemiş; genellikle felsefi düşünceye bağlı olarak gerçekleştirilmiştir.

Günümüzde mimarlık üretimi çizimlerle, görsel temsiller ve teknolojik olanakların gelişimiyle bilgisayar destekli ortamlarda farklı biçimlerde gerçekleşse de mimarlık disiplini kendini mimarlık bilgisi, mimarlık kuramı ve mimarlık tarihi gibi alanlarda metinsel olarak ifade etmeye devam etmektedir. 
İlkel dönemden günümüze mekân aslında bir mesaj taşır, insanlar mekân aracılığıyla birbirleriyle ve fiziksel çevreyle iletişim kurarlar. İlkel çağın mağara resimleri ve yazıları, insanların mekân yoluyla birbirleriyle iletişim kurduklarının ve mekân içerisinde ortak bir iletişim dili oluşturduklarının göstergesidir. Massachusetts Teknoloji Enstitüsü'nden (MIT) dilbilimci Shigeru Miyagawa, Lesure ve Nobrega tarafından yapılan araştırmalarda mağara yazılarının insanlığın sembolik ve çok yönlü dil/iletişim becerilerinin gelişimine dair önemli ipuçları sunduğu sonucuna ulaşılır (Miyagawa ve diğ., 2018). Günümüzde kent içerisinde yer alan binalarda, açı alanlarda bulunan reklam/afiş/tabela/yazılar yine mekân ve mekânsal unsurlar aracılığıyla bireylerin birbiriyle ve çevreyle kurduğu iletişimin farklı biçimleridir. Mısır tapınaklarında, mezar ve dikilitaşlarında bulunan yazılar, mekânın metinle ilişkisinin mekânda görünürlügünün ilk örneklerindendir. Romalıların bezeme tekniği ile sütun, alınlık, silme gibi yapısal elemanlar üzerindeki dilsel ifadeleri de dönemin iletişim kurma, yaşanan tarihsel olayları anlatma biçimlerindendir. İslam mimarisinde de özellikle dini yapılarda dinsel unsurların yapıya aktarıldığını, çeşitli ayetlerin yapıya entegre edildiği görülmektedir. Yapımetin ilişkisi mimaride döneme, dönemin yaşayış ve inanış şekline, teknolojik gelişmelere bağlı olarak farklılık göstermiştir.

\section{Yöntem}

Mimarlık ve edebiyat ara kesitinde iki disiplini de besleyen dinamikleri ortaya çıkarmak, disiplinler arası araştırmaları bu alanlarda genişletmek hedefiyle hareket eden makale, kapsamına iki disiplinin ortak paydasında yapılmış/tamamlanmış yüksek lisans ve doktora düzeyindeki ulusal tez çalışmalarını alır. Makalede, Yükseköğretim Kurulu (YÖK) Yayın ve Dokümantasyon Daire Başkanlığ 1 Şube Müdürlüğü'nün bünyesinde 1984 yılında kurulan ve 1987 yılından itibaren tamamlanmış lisansüstü tezlere erişim imkânı sunan Ulusal Tez Merkezi üzerinden ulaşılan lisansüstü tezler ele alınmaktadır. Mimarlık ve edebiyat alanında 1987 yılından günümüze tamamlanan tez çalışmaları Ulusal Tez Merkezi'nin veri tabanında her iki alanın da temel kavramları olan "mimarlik, edebiyat, dil, mekân, kent, roman, metin vb." gibi anahtar kelimelerle taranmıştır.

Her iki disiplinin kurucu kavramlarıla yapılan taramalar sonucunda ulaşılan yüksek lisans/doktora tezleri, tezin yazarı, tezin yürütücüsü, tezin tamamlandığı yıl, tezin gerçekleştirildiği yükseköğretim kurumu/enstitü/anabilim dalı, tezin derecesi ve tezin içeriğinde yer alan anahtar kelimeler olarak 
listelenmiştir. Mimarlık ve edebiyatın birbiriyle ilişkisinin akademik perspektifle lisansüstü tez çalışmalarının listelenmesiyle elde edilen tablo (EK.1) içerik analizi yöntemi ile değerlendirilmiştir.

Bu değerlendirme EK.1 de yer alan tabloda yer alan parametrelere bağlı olarak yapıldığ için mimarlık ve edebiyat ilişkisine yüzeysel bir bakışla bakmaz; alanın alt başlıklarına, anahtar kavramlarına dair de analitik çıarımlar yapmaya olanak sağlar. Mimarlık ve edebiyat ekseninde mimarlık ortamına kıymetli çalışmalar sunan Gürhan Tümer'e (1982) göre mimarlık mesleği ve mimarlık bilgisi ile ilgili yapılan çalışmalarda mimar olmayan ve mimarlık eğitimi almamış yazarların mekâna ve mimariye bakışlarının irdelenmesi mimarlık araştırmalarına katkı koyar. Makale, mimarlık ve mekânın bilgisinin yalnızca mimarlık disiplini ve çalışmalarıyla değil sosyal bilimler alanından diğer disiplinlerin alana koyacağı olumlu katkıyı da göz önünde bulundurur ve mimarlık ve edebiyat ilişkisine bu disiplinler arası bakış açısıyla odaklanır. Çalışma kapsamında Mimarlık ve edebiyat arakesitinde geçmişten günümüze tamamlanmış lisansüstü tezlerin analizi, bu iki alanda var olan mevcut bilginin ortaya koyar ve bundan sonra yapılacak araştırmalar için bir çerçeve oluşturur.

\section{Mimarlık ve Edebiyat İlişkisinin Lisansüstü Tez Çalışmalarıyla İrdelenmesi}

Günümüzde disipliner/disiplinler arası etkileşimlerin yoğun olarak gerçekleşmesinin doğal bir sonucu olarak bilgi alanlarının sınırları genişlemiş, farklı araştırma ve bilgi üretim yöntemleri ortaya çıkmıştır. Bu etkileşimli bilgi üretimi akademik çalışmalara da yansımıştır. Akademik çalışmalarda disiplinler arası etkileşimin artmasının bir sonucu olarak her disiplin salt kendi alanına ait formel yöntemlerden faydalanmak yerine başka disiplinlerin yöntem ve araçlarını da kullanır hale gelmiştir. Farklı disiplinlerin ortak paydasında farklı yöntem ve araçlarla üretilen ortak bilgi temas ettiği toplumsal alanların her birine katkı koymakta, alanlara yeni perspektifler açmaktadır.

Ulusal Tez Merkezi'nin dijital veri tabanında "mimarlk, edebiyat, mekân, metin, kent, dil, roman" anahtar kelimeleriyle yapılan detaylı taramalarla mimarlık ve edebiyat arakesitinde gerçekleştirilmiş 125 adet akademik çalışmaya erişilmiştir (Ek:1). Makale kapsamında ele alınan yüksek lisans/doktora tezleri çeşitli parametrelerle detaylı olarak listelenmiştir. Ulusal Tez Merkezi'nden ulaşılan tezler;

- Tezin Başlı̆̆

- Tezin Yazar, 
- Tezin Yürütücüsü,

- Tezin Tamamlandiğ Y Yl,

- Tezin Düzeyi (Yüksek Lisans/Doktora),

- Tezin Tamamlandiğı Yükseköğretim Kurumu/Enstitü/Anabilim Dalı,

- Tezde Belirlenen Anahtar Kelimelerine, göre detaylı olarak ele alınmıştır.

Makale kapsamında erişilen lisansüstü tezlerin yukarıda bahsedilen parametrelere göre ele alınmasının sebebi, incelenen tezlerden mimarlık ve edebiyat alanlarında gerçekleştirilen bilgi akışının hangi kanallardan, hangi yıllarda, hangi kurum ve enstitülerde ve hangi kavramlar etrafında ele alınd1ğına dair geniş bir çerçeve çizebilmektir.

Araştırma kapsamında elde edilen 125 adet lisansüstü çalışmanın geneli yüksek lisans düzeyinde gerçekleştirilmiştir. 100 adet yüksek lisans tezi, 24 adet doktora tezi ve 1 adet sanatta yeterlik tezi tespit edilmiştir (Tablo.1). Alanda doktora düzeyinde araştırmaların artması mimarlık ve edebiyat ilişkisinin akademik çerçevesini genişletecektir.

Tablo 1. Mimarlık ve Edebiyat alanında yapılan tezlerin enstitüye göre dağılımı tablosu

\begin{tabular}{ll}
\hline Tez Türü & Tez Sayısı \\
\hline Yüksek Lisans & 100 \\
\hline Doktora & 24 \\
\hline Sanatta Yeterlik & 1 \\
\hline Toplam & $\mathbf{1 2 5}$ \\
\hline
\end{tabular}

Mimarlık ve edebiyat ilişkisini irdeleyen lisansüstü tezlerin tamamlandıkları yıllara göre dağılımı incelendiğinde 1987 yılından günümüze yapılan çalışmaların giderek arttığı sonucuna ulaşılmaktadır. 1990 yılında bu alanda yapılmış 1 adet teze ulaşılmışken 2010-2020 yılları arasındaki 10 yıllık süreçte 78 adet tez alana katkı sağlamıştır (Tablo.2). Mimarlık ve edebiyat arakesitinde tamamlanan tezlerin giderek artması, makalenin kavramsal kısmında da belirtilen toplumsal gelişmelerle birlikte artan disiplinler arası etkileşimlerin sonucudur.

Tablo 2. Mimarlık ve Edebiyat alanında yapılan tezlerin tamamlandığı yılların yıllara göre yoğunluk tablosu

\begin{tabular}{ll}
\hline Tez Zaman Aralı̆̆1 & Tez Sayısı \\
\hline $1987-1990$ & 1 \\
\hline $1991-2000$ & 7 \\
\hline $2001-2010$ & 39 \\
\hline To11-2020 & 78 \\
\hline
\end{tabular}


Mimarlık ve edebiyatın birbiriyle ilişkisinin lisansüstü tezlerde genellikle sosyal bilimler alanı tarafından ele alındığı görülmektedir. Edebiyatın Türk Dili ve Edebiyatı, Türkçe/Edebiyat Öğretmenliği, Dilbilim gibi çeşitli uzmanlık alanlarında alt bölümlerinin olmasından dolayı bu alandaki lisansüstü tez çalışmaları sosyal bilimlere ait araştırma ve konuların ağırlığıyla sürdürülmektedir (Tablo 3).

Tablo 3. Mimarlık ve Edebiyat alanında yapılan tezlerin tamamlandıkları enstitüye göre dağjlımı tablosu

\begin{tabular}{ll}
\hline Enstitü & Tez Sayısı \\
\hline Sosyal Bilimler Enstitüsü & 73 \\
\hline Fen Bilimleri Enstitüsü & 36 \\
\hline Ekonomi ve Sosyal Bilimler Enstitüsü & 5 \\
\hline Türkiyat Araştırmaları Enstitüsü & 5 \\
\hline Lisansüstü Programlar Enstitüsü & 2 \\
\hline Güzel Sanatlar Enstitüsü & 1 \\
\hline Eğitim Bilimleri Enstitüsü & 1 \\
\hline Lisansüstü Eğitim Enstitüsü & 1 \\
\hline Lisansüstü Eğitim Öğretim ve Araştırma Enstitüsü & 1 \\
\hline Toplam & $\mathbf{1 2 5}$ \\
\hline
\end{tabular}

Mimarlık ve edebiyat alanlarına ait temel kavramlarla yapılan taramalar sonucunda elde edilen lisansüstü çalışmalar, tezlerin tamamlandığı anabilim dallarına göre listelendiğinde mimarlık ve edebiyat ilişkisinin Türk Dili Edebiyatı ve Mimarlık anabilim dallarında gerçekleştirildiği görülmektedir. Çalışmalarda Türk Dili ve Edebiyatı bölümünden 48 adet çalışma tespit edilmişken mimarlık alanından gerçekleştirilen tez sayısının 40 olduğu görülmüsştür. Mimarlık ve edebiyat ilişkisi yalnızca kurucu disiplinleri olan mimarlık ve edebiyat alanı tarafında değil, çok sayıda farklı disiplinin farklı anabilim dalları tarafından ele alınmıştır. Dilbilim ile ilgili disiplinler (İngiliz Dili ve Edebiyatı, Alman Dili ve Edebiyatı, Rus Dili ve Edebiyatı, Fransız Dili ve Edebiyatı, Karşllaştırmalı Edebiyat), Güzel Sanatlar, Balkan Çalışmaları, Siyaset ve Sosyal Bilimler, Kültürel Çalışmalar, Tasarım Çalışmaları farklı anabilim dallarından bazılarıdır (Tablo 4). Mimarlık ve edebiyat alanındaki lisansüstü tez çalışmalarının mimarlık anabilim dalında giderek arttığı ve alanın mimari bakış açısıyla farklı değerlendirmelere de açık bir alan olduğu görülmektedir.

Tablo 4. Mimarlık ve Edebiyat alanında yapılan tezlerin anabilim dalı tablosu

\begin{tabular}{ll}
\hline Anabilim Dalı & Tez Sayısı \\
\hline Türk Dili ve Edebiyatı & 48 \\
\hline Mimarlık & 40 \\
\hline İngiliz Dili ve Edebiyatı & 9 \\
\hline
\end{tabular}




\begin{tabular}{ll}
\hline Karşılaştırmalı Edebiyat & 5 \\
\hline Sosyoloji & 5 \\
\hline Sanat Tarihi & 3 \\
\hline İç Mimarlık ve Çevre Tasarımı & 3 \\
\hline Alman Dili ve Edebiyatı & 2 \\
\hline Antropoloji & 1 \\
\hline Fransız Dili ve Edebiyatı & 1 \\
\hline Güzel Sanatlar Eğitimi & 1 \\
\hline Balkan Çalışmaları & 1 \\
\hline Felsefe ve Toplumsal Düşünce & 1 \\
\hline Tasarım Çalışmaları (İç Mimarlık ve Dekorasyon) & 1 \\
\hline Siyaset ve Sosyal Bilimler & 1 \\
\hline Slav Dilleri ve Edebiyatı (Rus Dili ve Edebiyatı) & 1 \\
\hline Kültürel Çalışmalar & 1 \\
\hline Kürt Dili ve Edebiyatı & 1 \\
\hline Toplam & $\mathbf{1 2 5}$ \\
\hline
\end{tabular}

Araştırma kapsamında ele alınan tezlerin tamamlandığı yükseköğretim kurumlarına bakıldığında ise fen bilimleri alanında mimarlık eğitimi veren İstanbul Teknik Üniversitesi'nde bu kapsamda yapılan tezlerin sayıca diğer üniversitelere göre fazla olduğu görülmektedir (Tablo 5). Bunun sebebinin ise sosyal bilimler alanından gerçekleştirilen tezlerin farklı kurumlar (İstanbul Üni., Marmara Üni. Ege Üni., vb. gibi) tarafından gerçekleştirilmesinden kaynaklanmaktadır.

Tablo 5. Mimarlık ve Edebiyat alanında yapılan tezlerin üniversitelere göre dağılımı

\begin{tabular}{ll}
\hline Üniversite Adı & Tez Sayısı \\
\hline İstanbul Teknik Üniversitesi & 19 \\
\hline Bilkent Üniversitesi & 6 \\
\hline Mimar Sinan Güzel Sanatlar Üniversitesi & 6 \\
\hline Yeditepe Üniversitesi & 6 \\
\hline Gazi Üniversitesi & 6 \\
\hline Orta Doğu Teknik Üniversitesi & 6 \\
\hline Marmara Üniversitesi & 5 \\
\hline İstanbul Üniversitesi & 5 \\
\hline İstanbul Bilgi Üniversitesi & 5 \\
\hline Fatih Sultan Mehmet Vakıf Üniversitesi & 4 \\
\hline Trakya Üniversitesi & 3 \\
\hline Eskişehir Osmangazi Üniversitesi & 3 \\
\hline Ege Üniversitesi & 2 \\
\hline Başkent Üniversitesi & 2 \\
\hline Sakarya Üniversitesi & 2 \\
\hline Atatürk Üniversitesi & 2 \\
\hline Kocaeli Üniversitesi & 2 \\
\hline Yıldız Teknik Üniversitesi & 2 \\
\hline Karadeniz Teknik Üniversitesi & 2 \\
\hline
\end{tabular}




\begin{tabular}{ll}
\hline Dumlupınar Üniversitesi & 2 \\
\hline Ankara Üniversitesi & 2 \\
\hline Hacettepe Üniversitesi & 2 \\
\hline İzmir Yüksek Teknoloji Enstitüsü & 2 \\
\hline Çukurova Üniversitesi & 2 \\
\hline Uludağ Üniversitesi & 2 \\
\hline Sabanci Üniversitesi & 1 \\
\hline Boğaziçi Üniversitesi & 1 \\
\hline Muğla Üniversitesi & 1 \\
\hline Van Yüzüncü Yil Üniversitesi & 1 \\
\hline İnönü Üniversitesi & 1 \\
\hline İstanbul Aydın Üniversitesi & 1 \\
\hline Selçuk Üniversitesi & 1 \\
\hline Afyon Kocatepe Üniversitesi & 1 \\
\hline İstanbul Kültür Üniversitesi & 1 \\
\hline Ardahan Üniversitesi & 1 \\
\hline Nevşehir Haci Bektaş Veli Üniversitesi & 1 \\
\hline Dokuz Eylül Üniversitesi & 1 \\
\hline Anadolu Üniversitesi & 1 \\
\hline Pamukkale Üniversitesi & 1 \\
\hline Fatih Üniversitesi & 1 \\
\hline İzmir Ekonomi Üniversitesi & 1 \\
\hline Frrat Üniversitesi & 1 \\
\hline Doğu Akdeniz Üniversitesi & 1 \\
\hline Muş Alparslan Üniversitesi & 1 \\
\hline Artvin Çoruh Üniversitesi & 1 \\
\hline Yaşar Üniversitesi & 1 \\
\hline Galatasaray Üniversitesi & 1 \\
\hline Atılım Üniversitesi & 1 \\
\hline Mersin Üniversitesi & 1 \\
\hline Balıkesir Üniversitesi & 1 \\
\hline Toplam & $\mathbf{1 2 5}$ \\
\hline & \\
\hline & 1 \\
\hline
\end{tabular}

Makalenin ekler kısminda detaylı olarak tablo haline getirilen tezlerde (EK.1) yer alan anahtar kelimeler mimari perspektiften gerçekleştirilen bu araştırmanın derinlemesine anlaşılabilmesi ve mimarlık bilgisini daha detaylı olarak ortaya koyması amacıyla analiz edilmiştir. Tezin içeriği ve ana kavramlarını büyük ölçüde içeren bu anahtar kelimeler, incelenen tezlerin mimari bakış açısı ve mimarlık kavramlarıyla değerlendirilmesi için önemli görülmektedir. Anahtar kelimeler tezin başlı̆̆ı, içeriği, bölümleri, hedefi ve yöntemiyle ilgili bilgi vermekte, mimarlık ve edebiyat ilişkisinin hangi alanlar/kavramlar/dönemler/yazarlar/eserlere göre ele alındığını ortaya koymaktadır. İncelenen lisansüstü tezlerde tespit edilen anahtar kelimeler, makalenin bundan sonraki kısımlarında çeşitli kategorilere göre tablo haline getirilmiştir. Anahtar kelimelerin mimarlığı ve edebiyatı etkileyen önemli tanımlara, 
kavramlara ve dinamiklere göre ayrılması, iki alanın ortak paydasında üretilen akademik bilginin mevcut eğilimi hakkında mevcut potansiyelleri ortaya koyması açısından ufuk açıcıdır.

Lisansüstü çalışmalarda yer alan anahtar kelimelerde, mimarlığı/mekânı etkileyen bazı edebi türlere rastlanmıştır. Mimarlık ve edebiyat arasındaki ilişki ağırlıklı olarak içerisinde mekânsal unsurları en fazla barındıran roman türünde ele alınmıştır. Romanı, mekânsal anlatımlar açısından güçlü hikâye ve öykü türleri izlemiştir. Şiir, çizgi roman, destan, drama, seyahatname ve söyleşiler de bu bağlamda ele alından diğer edebi türlerdir (Tablo 6). Roman, hikâye ve öykü türüne ait edebi eserler konularına göre incelendiğinde kurgusal mekâna ait unsurları içeren ütopya, bilimkurgu ve distopya türü bu alanda en sık karşılaşılan anahtar kelimeler olmuş; bunları çeviri, çizgi roman, destan, şiir ve drama gibi diğer edebi türler izlemektedir (Tablo 7).

Tablo 6. Mimarlık ve Edebiyat alanında yapılan tezlerde yer alan anahtar kelimelerin edebi türlere göre dağılımı

\begin{tabular}{ll}
\hline Edebi Türler & Tez Sayısı \\
\hline Roman & 25 \\
\hline Hikâye & 8 \\
\hline Öykü & 5 \\
\hline Şïr & 2 \\
\hline Çizgi Roman & 1 \\
\hline Destan & 1 \\
\hline Drama & 1 \\
\hline Seyahatname & 1 \\
\hline Söyleşi & 1 \\
\hline
\end{tabular}

Tablo 7. Mimarlık ve Edebiyat alanında yapılan tezlerde yer alan edebi türlerin konularına göre dağılımı

\begin{tabular}{ll}
\hline Edebi Türler Konu & Tez Sayısı \\
\hline Ütopya & 8 \\
\hline Bilimkurgu & 4 \\
\hline Distopya & 3 \\
\hline Feminist Distopya & 1 \\
\hline
\end{tabular}

Edebiyatta mekânsal unsurlar yalnızca mimari mekâna değil coğrafi mekâna, peyzaja, özelleşmiş yer adlarına da işaret etmektedir. Edebi metinde anlatılmak istenen olay örgüsü, işlenmek istenen karakterler çoğu zaman mekânsal bir betimlemeye veya herkes tarafından anlaşlır bir yer adına ihtiyaç duymaktadır. Bu anlamda anahtar kelimeler özelleşmiş yer/bölge adlarına göre bir sınıflandırmaya tabi tutulmuştur. İncelenen tez çalışmalarında edebiyat alanında en çok "İstanbul" ve İstanbul'da geçen edebi eserlerin ele 
alındığı görülür. İstanbul gerek tarihsel unsurları gerekse Türkiye'de edebiyat üretiminin hem merkezi hem de yönlendiricisi olarak ön plana çımıştır. Geçmişte yaşanan olayları konu alan tarihsel romanların ele alındığı tezlerde Türkiye siyasi tarihinin ve toplumsal ortamın edebi üretime etki ettiği görülmektedir. Tanzimat Dönemi, Erken Cumhuriyet Dönemi ve sonrası edebi eserlere mekânsal olarak da yansımıştır. Bu bağlamda tarihsel romanlar bulundukları coğrafyanın toplumsal ortamından oldukça etkilenmiştir. İstanbul'dan sonra Erken Cumhuriyet Dönemi eserleriyle birlikte Ankara kenti edebi eserlere sıklıkla konu olmuştur. Benzer şekilde Türkiye modernleşme sürecinde Modern Türk Edebiyatı'ndaki Fransız etkisi sebebiyle dönemin edebiyatçıları Fransız Edebiyatı'ndan ve toplumsal/sanatsal/kültürel ortamından etkilenmiştir. Paris ve Fransa bu bağlamda edebi eserlere modernleşme hareketi bağlamında etki etmiştir (Tablo 8). Mimarlık ve edebiyat ilişkisini konu alan özelleşmiş yerlere bakıldığında Türkiye edebiyat ortamı açısindan zengin eserlere konu olan Anadolu coğrafyasının yeterince irdelenemediği görülmektedir. Bunun sebeplerinden birisinin modernleşmenin hızlı bir şekilde gerçekleşmesi ve tüm toplumsal sistemlere hızlı bir şekilde entegre edilmek istenmesiyle Batı toplumlarının örnek alınması ve batılılaşma hareketleri olduğu düşünülmektedir. Modernleşmenin bu denli hızlı gerçekleşmesi, Anadolu coğrafyasının yoksulluk, eğitim ve kültür seviyesinin yüksek olmaması sebebiyle geri plana atılmasına sebep olmuştur.

Tablo 8. Mimarlık ve Edebiyat alanında yapılan tezlerde yer alan anahtar kelimelerin yer adlarına göre dağılımı

\begin{tabular}{ll}
\hline Ülke / Şehir / Bölge / Coğrafya & Tez Sayısı \\
\hline İstanbul & 12 \\
\hline Ankara & 3 \\
\hline İzmir & 2 \\
\hline Beyoğlu & 2 \\
\hline New York & 1 \\
\hline Ayasofya & 1 \\
\hline Anadolu & 1 \\
\hline Bursa & 1 \\
\hline Paris & 1 \\
\hline Balkanlar & 1 \\
\hline Kafkasya & 1 \\
\hline Adana & 1 \\
\hline Rusya & 1 \\
\hline Cezayir & 1 \\
\hline Fransa & 1 \\
\hline
\end{tabular}


Makalenin bu kısminda incelenen 125 adet lisansüstü tezde yer alan anahtar kelimelerden mimarlıkla doğrudan ilgili kavramlar süzülmüş ve mimari bakış açısıyla sınıflandırılmıştır. Aşağıda mimarlıkla doğrudan ilgili anahtar kelimelerin en çok tekrar edilenleri listelenmiştir. Lisansüstü tezlerde mimarlıkla ilgili kavramlardan en çok tekrar eden kelimenin "mekân" olduğu, sonrasında "kent, mimarlık ve mimari" kelimeleri olduğu tespit edilmiştir (Tablo 9). Lisansüstü çalışmalarda kentsel unsurların, kent ile ilgili kavramların sıklıkla yer alması mimarlık ve edebiyatın toplumsal ortamla ve bunun mekânsal karşılığı olan kent ile kurduğu güçlü ilişkiden kaynaklanmaktadır.

Tablo 9. Mimarlık ve Edebiyat alanında yapılan tezlerde yer alan anahtar kelimelerin mimarlık disiplinine ait kavramlar listesi

\begin{tabular}{ll}
\hline Mimarlık Disiplini ile ilgili kavramlar & Tez Sayısı \\
\hline Mekân & 44 \\
\hline Kent & 10 \\
\hline Mimarlık & 9 \\
\hline Mimari & 4 \\
\hline Şehir & 3 \\
\hline Zaman-Mekân & 4 \\
\hline Kentlileşme & 3 \\
\hline Mimarlık Tarihi & 2 \\
\hline Yer & 2 \\
\hline Ev & 2 \\
\hline Mimari Temsil & 2 \\
\hline İnsan-Mekân İlişkisi & 2 \\
\hline Kent Kimliği & 2 \\
\hline Kentleşme & 2 \\
\hline
\end{tabular}

Makale, mimarlık disiplininde, mimarlık disiplininin dinamikleri göz önünde bulundurularak üretildiği için yukarıda listelenen mimarlıkla doğrudan ilgili kavramlar mimari bakış açısıyla değerlendirilmektedir. Mimarlık kavramları, mimari akımlar, kentsel ve mekânsal unsurlar mimarlık disiplininin öğretileri bağlamında ele alınmaktadır. Tezlerde bahsedilen anahtar kelimelerde geçen mimarlıkla ilgili en genel kavramların "mekân, kent, mimarlık ve mimari" olduğu görülür. Mekânın farklı türleri ve tanımlamaları lisansüstü çalışmalarda yer almış olup bu bağlamda en çok tartışılan mekânın "yazınsal mekân" olduğu görülmektedir. "İç mekân, Dış mekân, Mimari mekân, Kurgusal mekân, Kentsel mekân, Çeoresel mekân, İdeolojik mekân, Ruhsal durumu yansitan mekân" gibi farklı mekân türlerinin de çalışmalarda ele alındığg görülür (Tablo 10). 
Tablo 10. Mimarlık ve Edebiyat alanında yapılan tezlerde yer alan anahtar kelimelerde yer alan mekân çeşitleri

\begin{tabular}{ll}
\hline Mekân Türleri & Anahtar Kelime Sayısı \\
\hline Yazınsal Mekân & 3 \\
\hline İç Mekân & 1 \\
\hline Diş Mekân & 1 \\
\hline Mimari Mekân & 1 \\
\hline Kurgusal Mekân & 1 \\
\hline Kentsel Mekân & 1 \\
\hline Çevresel Mekân & 1 \\
\hline İdeolojik Mekân & 1 \\
\hline Ruhsal Durumu Yansıtan Mekân & 1 \\
\hline
\end{tabular}

Çalışmalarda özelleşmiş mimari unsurlara ve yapılara da sıklıkla rastlanmaktadır. Belli bir dönemi anlatan edebi eserlerde ve tarihi romanlarda dönemin toplumsal ortamını yansıtan, gündelik hayatın geçtiği mekânlara yer verilmektedir. Gündelik hayatın geçtiği ve toplumsal hayatın başladığı yer olan ev gerek romanda gerekse şiirde mekânsal olarak ön plandadır. Tanzimat dönemi ve sonrasında Türk Edebiyatında konak, yalı, köşk gibi sosyoekonomik gücün ve aile yaşantısının bir yansıması olan mekânsal anlatılara rastlanmaktadır. Cumhuriyet' in bir yaşam biçimine dönüşerek toplumsal yapılara entegre olmasıyla, Modern Türk edebiyatı modernizmin etkisinde kalmıştır. Modern Türk Edebiyatıyla birlikte apartman ve konut gibi gündelik yaşam mekânlarının edebi anlatılarda yer aldığı görülmektedir. Apartman ve konut modernizmin ve batılllaşmanın mekândaki göstergesi olmakla birlikte dönemin edebi eserlerinde apartman ve konut mekanları bireyselleşme, yabancılaşma gibi kavramlarla tartışılmıştır (Tablo 11).

Tablo 11. Mimarlık ve Edebiyat alanında yapılan tezlerde yer alan anahtar kelimelerdeki Özelleşmiş mekânlar listesi

\begin{tabular}{ll}
\hline Gündelik Yaşam Mekânları & \\
\hline Ev & Konut \\
\hline Konak & Müze \\
\hline Köşk & Otel \\
\hline Yalı & Köy \\
\hline
\end{tabular}

Toplumsal ilişkilerin gerçekleştiği yer olan mekân, mimarlığın fiziksel üretimi olmakla birlikte birçok disiplinin de üretiminin merkezinde yer alır. Mekân bu çok yönlü durumuyla kullanıcısıyla ve çevresiyle sürekli olarak ilişki içerisindedir. İncelenen tezlerde yer alan anahtar kelimelerde mekânın fiziksel, psikolojik, çevresel, toplumsal birçok yönüyle yer aldığı görülmekte- 
dir. Bu kavramların yalnızca mimarlık alanında değil psikoloji, sosyoloji, felsefe, edebiyat gibi diğer toplum bilimlerindeki çalışmalarda da ele alındığını bu anlamda da mekân kavramının bilimsel bir olgu olarak tartışılmaya devam ettiğini söyleyebiliriz (Tablo.12).

Tablo 12. Mimarlık ve Edebiyat alanında yapılan tezlerde yer alan anahtar kelimelerdeki mekânla ilgili fiziksel/psikolojik/çevresel/toplumsal kavramlar

\begin{tabular}{ll}
\hline \multicolumn{2}{l}{ Mekânla ilgili fiziksel/psikolojik/çevresel/toplumsal kavramlar } \\
\hline Mekân Sosyolojisi & Mekânsal Dönüş \\
\hline Mekânda Feminenlik ve Maskülenlik & Mekânsal Davranış \\
\hline Mekânda Mahremiyet ve Kamusallık & Mekânsal Analiz \\
\hline Mekânın Poetiği & Mekânsal Öğe \\
\hline Mekânın Psikolojik Boyutu & Mekânsal Yapı \\
\hline Mekânın Sosyal Boyutu & Mekânsılaştırma \\
\hline Mekânsal Alg1 & İnsan-Mekân İlişkisi \\
\hline
\end{tabular}

Mimarlığa ait teorik yaklaşımlar mimarlık ve edebiyat ilişkisini ele alan lisansüstü çalışmalarda farklı şekillerde tartışılmaktadır. Mimarlık sosyal bilimler alanından kuram, eleştiri, felsefe ve söylem olarak dilden ve yazıdan etkilenmektedir. Bu etki, makale kapsaminda incelenen tezlerde yer alan anahtar kelimelerde de gözlenmektedir. Mimarlık edebiyat ilişkisi çalışmalarda dil, temsiliyet, gibi kavramlarm yanı sıra siber-uzay, bilgisayar destekli tasarım gibi güncel yaklaşımlarla da ele alınmaktadır (Tablo 13).

Tablo 13. Mimarlık ve Edebiyat alanında yapılan tezlerde yer alan anahtar kelimelerdeki mimarlıkla ilgili kavram/yöntem/yaklaşımlar listesi

\begin{tabular}{ll}
\hline \multicolumn{2}{l}{ Mimarlık ile ilgili teorik kavramlar/yöntemler/yaklaşımlar } \\
\hline Mimarlık & Mimarlık Söylemi \\
\hline Mimari Dil & Tasarım \\
\hline Mimari Eleştiri & Tasarım Tarihi \\
\hline Mimari Eser & Siber-Uzay \\
\hline Mimari Tasarım & Bilgisayar Destekli Tasarım \\
\hline Mimari Temsil & \\
\hline
\end{tabular}

Mimarlık ve edebiyatın ifade aracı olan dil ve metin toplumsal yönüyle aynı zamanda kentsel alanın da bir unsuru olarak karşımıza çıkar. İncelenen tezlerde kent kavramının farklı bakış açılarıyla tartışıldığı görülmektedir. Kent fiziksel durumunun yanı sıra kentli olmak, kentleşme ve kentsel deneyim gibi kavram/durumlarla tartışılmaktadır. Kentin birçok disiplinden beslenen çok yönlü etkileşimli hali, kenti birçok disiplinin araştırma laboratuvarı haline getirir. Kent mimarlıkta da edebiyatta da, araştırılmaya açık devingen bir deneyim alanıdır (Tablo 14). 
Tablo 14. Mimarlık ve Edebiyat alanında yapılan tezlerde yer alan anahtar kelimelerdeki Kentsel Kavramlar Listesi

\begin{tabular}{ll}
\hline Kentsel Kavramlar & \\
\hline Kent & Kentsel Analiz \\
\hline Kentlileşme & Kentsel Deneyimleme \\
\hline Kentleşme & Kentsel Mekân \\
\hline Kent İlişkisi & Şehirleşme \\
\hline
\end{tabular}

\section{Sonuç ve Değerlendirmeler}

Mimarlık ve Edebiyat gibi fen bilimleri ve sosyal bilimler alanlarının iki önemli disiplini günümüz etkileşimli ortamında toplumsal yaşantı ve ilişkilerle birlikte iç içedir. Mimarlık dille, yazıyla kendi disiplinini metinsel olarak kurar, organize eder. Mimarlık kuramı, eleştirisi ve söylemi de dile ve metne dayalıdır. Mimarlık nesneleri, çoğu zaman hem mimari üslubu hem de taşıdığı mesajla dile ve iletişime dayalıdır. Edebiyat da okuyucusu ile ortak bir dille iletişim halinde bir üretimdir.

Mimarlığın edebiyatla ilişkisinin temelinde iletişim kurma vardır. Bu iletişim temel öğretileri ve üretimleri farklı iki alan için disiplinler arası olarak gerçekleşir. Birbiriyle benzer veya aynı olmayan her durum her zaman farklı olandan beslenme potansiyeli barındırır. Disiplinler arası ilişkilerin kurulması, alanların birbirini beslemesi açısından faydalıdır. Edebiyat da mimari de toplumun birçok kanalından beslenen sanatsal üretimlerdir. Toplumsal alana dokunan, toplumsal dinamiklere temas halinde her ilişkide disipliner sınırlar, alanı geniş bir perspektifle değerlendirmeye açık hale getirir.

Bilgi ve iletişim teknolojilerinin artması ile insanlar, nesneler, durumlar, uzmanlıklar arasındaki katı sınırların erimeye başladığı görülmektedir. Bu durum mimarlık ve edebiyatında sınırlarını belirsizleştirmiş mimarlıkla dilin, yazının, edebiyatın ilişkisi, edebiyatta mekânın yeri, kullanım biçimi ve edebi üretime etkileri tartışılmaya başlanmıştır.

Makale, mimarlık ve edebiyat arasında kurulan çok yönlü ilişkiye hem mimarlığın hem de edebiyatın dinamikleri üzerinden geniş bir çerçeveden akademik olarak bakabilmeyi hedeflemiştir. İki disiplinin kurucu dinamikleri akademik perspektifle lisansüstü ulusal tez çalışmalarıyla incelenmiştir. Böylelikle Türk edebiyatı ve mimarlık üretimi arasındaki ilişkiye dair yapılmış lisansüstü tez çalışmalarının bir çerçevesi çizilebilecek, çalışılan konu/kavram/yazar/kent/yönteme dair bir sınıflandırma imkânı olabilecektir. İncelemeler sonunda ulaşılan 125 adet lisansüstü tez çalışmasıyla ilgili olarak; 
- Tezlerden 100 tanesi yüksek lisans düzeyinde, 24 tanesi doktora düzeyinde, 1 tanesi ise sanatta yeterlilik tezidir.

- Tezlerin yoğun olarak sosyal bilimler alanından araştırmacılar tarafından gerçekleştirilmiştir. Mimarlık disiplininde, bu ilişki mimari bakış açısıyla farklı araştırma ve değerlendirilmelere açıktır.

- Dilbilim alanı çok geniş ve bünyesinde farklı uzmanlık alanını barındırdığı için edebiyat alanında bu araştırmaların Türk Dili ve Edebiyatı bölümü başta ve ağırlıkta olmak üzere İngiliz, Fransız, Rus, Alman Dili ve Edebiyatı, Karşılaştırmalı Edebiyat gibi farklı anabilim dallarında sürdürülmektedir.

- Mimarlık alanındaki çalışmalar ise genelde mimarlık anabilim dalı mimari tasarım bölümünde yoğunlaşmıştır. Mimari tasarımı bölümünü, iç mimarlık ve mimarlık tarihi bölümlerinde tamamlanan az sayıdaki çalışmalar izlemektedir.

- Çalışmalara ağırlıklı sosyal bilimler alanı etki etmiş olsa da tezlerin tamamlandığı üniversitelere bakıldığında mimarlık eğitimi veren İstanbul Teknik Üniversitesi'nin bu alanda en çok çalışma yapılan yükseköğretim kurumu olduğu görülmüştür. Mimarlık disiplininde mimari bir bakışla yazılmış bu makale için bu durum, mimarlık ve edebiyat ilişkisinin araştırılıp tartışmaya açılması için motive edicidir.

- Tezlerde yer alan anahtar kelimeler analiz edildiğinde, bazı edebi türlerdeki mekânsal durumların belirgin olduğu görülmüştür. En fazla araştırmanın roman türü üzerine olduğu, romanı hikâye ve öykü gibi türlerin izlediği görülmektedir. Roman, hikâye ve öykü türleri mekânsal anlatılardır ve bu edebi türlerde işlenen olaylar, kurgulanan karakterlerin anlaşılması için iyi kurgulanmış mekânsal anlatımlara ihtiyaç duyulmaktadır. Kurgusal mekâna dair bir anlatı biçimi olan ütopya, distopya ve bilimkurgu bu alanda yoğun olarak çalışılan roman, hikâye, öykü türleri olarak tespit edilmiştir.

- Mekân unsuru aynı zamanda bir coğrafyaya, kente veya kentsel parçaya işaret ettiği için tezlerde yer alan anahtar kelimelerde İstanbul, Ankara, Beyoğlu, Fransa ve İzmir gibi özel yer adlarına rastlanmıştır.

- İncelenen lisansüstü çalışmalardaki mimarlıkla doğrudan ilişkili kavramlar listelendiğinde alanın mimarlı̆ıın fiziksel, sosyal, psikolojik açıdan farklı kavram ve durumlarla ele alındığı görülmüştür. Mimarlık disiplinini toplumsal yönünü ön plana çıkaran bu durum sayesinde edebi eserler mekânsal açıdan farklı okumalara açk hale gelmektedir. 
- Mimarlık disiplini ile doğrudan ilişkilendirilen anahtar kelimelerin mimari bakış açısıyla farklı değerlendirmelere açık olduğu görülmüştür. Çalışmada bu kelimeler mimarlıkla, kentle, mekânla ilgili kavramlar ve özelleşmiş mekânlar olarak gruplandırılmıştır. Bu sınıflandırma alanın teorik, kuramsal bilgisi, yöntem ve ilişki biçimine dair derinlikli bir değerlendirme yapılabilmesine olanak sağlamaktadır.

- Mimarlık ve edebiyat ilişkisi lisansüstü tezlerde, Türk Edebiyatının ve mimarlığının geçirdiği dönüşüme paralel olarak belli dönem ve belli yazarlar, o yazarların belli eserleri, belli mekân tipleri, toplumsal dönüşümün yansıdığı belli mekânsal ilişkiler üzerinde yoğunlaştığı görülmüştür. Tanzimat dönemi, Erken Cumhuriyet Dönemi en fazla araştırma yapılan dönem olmakla birlikte dönemin edebiyatçllarından Ahmet Hamdi Tanpınar, Ahmed Midhat Efendi, Peyami Safa, Yakup Kadri Karaosmanoğlu lisansüstü çalışmalarda anahtar kelime olarak yer alan edebiyatçılardan bazılarıdır. Mihail Bahtin, Franco Moretti, Georges Lukács, Gérard Genette, Yuri Lotman gibi edebiyat teorisyenlerinin de tezlerde yer aldığı görülmektedir. Özellikle Türk edebiyatında batılılaşma süreciyle belirgin şekilde etkisini gösteren Fransız edebiyatı yazar ve şairlerin yanı sıra edebiyat kuramcıları açısından da dönemin Türk edebiyatçılarına etkisi olmuştur.

- Mimarlık ve edebiyat ilişkisine dair yapılan çalışmaların geçmişten günümüze artarak sürdürülmesine ve ağırlıklı olarak İstanbul'u konu alan eserlerin yer almasına paralel olarak bu alanda en fazla araştırmanın Orhan Pamuk ve romanları üzerinde yapıldığı görülür. Pamuk'un da tamamlayamamış olsa da mimarlık eğitimi almış bir yazar olmasının ve mimari bakış açısını ve kişisel deneyimlerini özellikle İstanbul coğrafyası üzerinde incelikle eserlerine yansıtmasından dolayı İstanbul ve Orhan Pamuk mimarlık ve edebiyat alanları için lisansüstü çalışmalarda sıklıkla irdelenmiştir. Postmodern edebiyat bağlamında Pamuk ile Elif Şafak, Latife Tekin, Tezer Özlü gibi postmodern edebiyatçllar da eserlerinde kurguladıkları mekânsal anlatılarla tezlerde yer almaktadırlar.

- Mimarlık ve edebiyat ilişkisi kapsamında incelenen lisansüstü çalışmalarda ele alınan edebi eserlerde, roman türünde eğilim, Türk edebiyatının geçirdiği dönüşüme paralellik gösterir. Tanzimat döneminin yaşantısını ve mekânsal ortamını anlatan tarihsel romanlardan, Erken Cumhuriyet Dönemi'nde ülkenin siyasi ortamındaki dönüşümle birlikte modernleşme süreciyle farklılaşan toplum yapısı modern edebiyat eserlerine ilgiyi arttırmıştır. Günümüzde ise içinde yaşadığımız postmodern toplum yapısı 
çoklu kavramlar/anlatıların hâkim olduğu, mekânsal ilişkilerin farklı şekillerde kurulduğu bir ortamdır. Postmodern toplum yapısıyla birlikte var olan postmodern edebiyat bu mekânsal ilişkileri eserlerinde bu bağlamda ele alır. Bunun yanı sıra yaşadığı ve edebi üretimde bulunduğu dönemde yeterince anlaşılamamış ve çalışılmamış Ahmet Hamdi Tanp1nar'ın da Tanpınar'ın mimariye, mekâna olan ilgisi ve hayranlığı sebebiyle günümüzde çok sayıda akademik araştırmanın da konusu olduğu görülmektedir.

- İncelenen tezlerde yer alan anahtar kelimelerde Le Corbusier, Louis I. Kahn, Bjarke Ingels gibi yabancı mimarların, Turgut Cansever, Şevki Balmumcu gibi Türk mimarlar yer almaktadır. Mimarlık teorisyeni Henri Lefebvre'nin ve mekân üçlemesinin de lisansüstü tezlerde yer aldığı görülmektedir.

Makalede, lisansüstü tez çalışmaları üzerinden ulusal tezlerin analiziyle mimarlık ve edebiyatın, mimari ile dilin, dil ile kentin, kent ile toplumun ilişkisi çok yönlü değerlendirmelere açık bir alan olarak tariflenir. Günümüzde mimarlık eğitimi veren okullarda, mimari stüdyo çalışmalarında, çeşitli atölye ve etkinliklerde gerçekleştirilen araştırma ve çalışmalar, her iki alanın bilgisini kullanarak farklı araştırmalar üretmeye devam ekmektedir. Mimarlık ve edebiyat ilişkisinin araştırmasının mimari bir bakışla gerçekleştirilmesi mimarlık disiplinine hiç kuşkusuz yeni perspektifler açacaktır. Bu yeni bakışla mimarlık disiplini de kendi mekânsal üretimlerini, kullandığı yöntem ve araçlarını geliştirmekte, çağın disiplinler arası etkileşimli ortamına ayak uydurmaktadır. 


\section{Extended Abstract}

\section{A Classification of Academic Studies on the Relationship between Architecture and Literature

\author{
Ayşe Pınar Serin Güner \\ ORCID: 0000-0003-4043-0219
}

\author{
Hikmet Gökmen \\ ORCID: 0000-0002-3568-8226
}

All kinds of production operating in the social field are related to each other. In today's interdisciplinary environment, the boundaries between the fields of knowledge are becoming blurred and even intertwined. Architecture is an artistic production field that constructs spatial relations, discusses social relations in a spatial context and is based on the practice of building. Literature realizes its artistic production by using the written language. In the article, the relationship between architecture and literature is based on the sociality of both disciplines and their use of their own professional languages. Architecture, with its own physical integrity, defines a visual architectural language within its own information production area with the tools it uses in the process of producing architectural information. Architecture realizes this language through visual images and their representation processes.

Architectural structures, which are the places where spatial communication takes place from the past to the present, are also architectural elements that carry a message on their own using the architectural language. In addition to the architectural language that architecture uses in its own discipline, there are also areas where architectural knowledge is maintained in writing.

The fields of architectural theory and architectural history that produce and discuss architectural knowledge theoretically continue this knowledge by using the written language. Within the scope of the article, the relationship of architecture with language is discussed in two ways in architectural perspective. The first is the relationship that architecture establishes with architectural language, and the other is the relationship between architecture and text. At the intersection of literature and architecture, the element of space and spatial relations are at the forefront. The element of space in literature realizes its literary expression through the concepts of fictional and physical space. The fictional or real space undertakes the task of making the event that is intended to be told in 
the literary work, the people of the literary work and the relationships between them in reader's mind more realistic. Within the scope of the article, the relationship between architecture and literature is handled from the perspective of literature with the dimension of spatial narratives in literary work.

The article discusses the relationship between literature and architecture as an interdisciplinary research area. In this article, after explaining the relationship between architecture and literature with society and each other conceptually, it examines how this relationship is carried out in the academic field. It examines the contribution of academic knowledge produced at the intersection of architecture and literature to the knowledge of both fields with the postgraduate theses registered in the thesis archive of the Higher Education Institution National Thesis Center (YOK) since 1987. Theses obtained as a result of the search with the keywords "Architecture, literature, space, text, language", which are the basic concepts in these two fields, have been tabulated within the scope of the article. In this context, the theses accessed are analyzed according to the thesis author, thesis supervisor, the year the thesis was completed, the university and department where the thesis was completed and keywords of the thesis. Content analysis method was used in the analysis of the relationship between architecture and literature in the context of graduate theses. 125 theses examining the relationship between architecture and literature have been reached. It has been determined that most of these theses are master's theses. Theses were mainly produced in the field of social sciences such as Turkish Language and Literature, Turkish Language Teaching, Comparative Literature, Linguistics. The number of researches produced in the field of science in theses dealing with the relationship between architecture and literature is less than the field of social sciences. Architecture discipline is the department with the most studies in this field in the institute of science. The relationship between architecture and literature is mostly studied in Istanbul Technical University (ITU), Department of Architecture, which is one of the universities that provide graduate education in our country.

The keywords in the theses in the article were analyzed in detail. When these keywords were examined, it was seen that the word place was repeated the most. As the number of repetitions, the word space is followed by the words of city and architecture. It is seen that most novel genres are studied in the keywords of theses. Story, short story, poetry are the most studied literary genres after novel. Utopia, dystopia, and science fiction literature are often discussed in the genre of novels and stories. The cities of Istanbul and Ankara are the most mentioned in the literary works dealt with in postgraduate thesis studies. In the 
keywords of the theses, different spatial expressions are encountered depending on different definitions of space: literary space, interior space, exterior space, architectural space, fictional space, urban space, environmental space, ideological space are some of these spatial expressions. The keywords in the theses also provide information about the places of everyday life. Daily life spaces and spatial relations have transformed depending on the social structure of the historical period in which literary works are discussed. Houses, mansions, residences, apartments, hotels and villages are some of the daily life spaces which are mentioned in the theses.

Within the scope of the article, the information about which writers and poets' works in which literary genres are discussed in the relationship between architecture and literature is reached in these theses that are examined. The article draws a theoretical framework between the disciplines of architecture and literature with the dimensions of language, writing and sociality. The article discusses how the current disciplinary knowledge of both fields is transformed with the interdisciplinary flow of information between architecture and literature. It explores how the boundaries of the field of knowledge of architecture in the field of architecture can be expanded using literature and literary works, from an architectural perspective. It reveals the current situation for new academic research to be produced at the intersection of architecture and literature disciplines and plays a guiding role for new research areas.

\section{Kaynakça/References}

Aksan, D. (2007). Her yönüyle dil ana çizgileriyle dilbilim (4. baskı). Ankara: TDK Yayınları.

Barthes Roland: (1979). Göstergebilim ilkeleri, (Çev. Berke Vardar, Mehmet Rifat). Ankara: Kültür Bakanllğı.

Bircan, U. (2015). Roland Barthes ve göstergebilim. Sosyal Bilimler Araştrma Dergisi, $13(26), 17-41$.

Çağlar, B. (2012). Bir iletişim biçimi olarak göstergebilim. LAÜ Sosyal Bilimler Dergisi, 3(2), 22-34. Erişim adresi: https://dergipark.org.tr/en/pub/euljss/issue/6282/84320

Çağlar, N., Ultav, Z. T., ve Boyacıoğlu, E. (2013). Sevgi Soysal ve yenişehir'de bir öğle vakti romanından mimari/kentsel mekâna ilişkin çıkarımlar. Dokuz Eylül Üniversitesi Edebiyat Fakültesi Dergisi, 2(3), 61-80.

Eco, U. (1979). A theory of semiotics. Bloomington : Indiana University Press.

Heidegger, M. (1971). On the way to language. (Translated. Peter D. Hertz). New York: Harper \& Row

Karadeniz, S., Günenç, Ö. F., \& Taşar, E. S. (2016). Uğur Tanyeli ile söyleşi: Toplumsallık üretim biçimi olarak mimarlık. Sosyoloji Divanı Sosyoloji Dergisi, (7), 233-247 
Kıran, A. (1990). Dilbilim-göstergebilim ilişkileri. Dilbilim Araştırmaları Dergisi, (1), 51-62. Erişim adresi: $\underline{h t t p: / / d a d . b o u n . e d u . t r / e n / p u b / i s s u e / 29234 / 312960 ~}$

Lefebvre, H. (2014). Mekânın üretimi. (Çev. Işık E.). İstanbul: Sel Yayıncılık. （Orijinal Yayın Tarihi, 1974).

Martinet, A. (1985). Işlevsel genel dilbilim. (Çev. Berke Vardar). Ankara: Birey ve Toplum Yayınları.

Miyagawa, S., Lesure, C., \& Nóbrega, V. A. (2018). Cross-modality information transfer: a hypothesis about the relationship among prehistoric cave paintings, symbolic thinking, and the emergence of language. Frontiers in Psychology, 9, 115.

Saussure de, F. (1985). Genel Dilbilim Dersleri. (Çev. Berke Vardar). Ankara: Birey ve Toplum Yayınları.

TDK Sözlük, (2020). Erişim adresi: https://sozluk.gov.tr/ Erişim Tarihi: 15.11.2020

Tümer, G. (1982). Mimarlik-edebiyat ilişkileri üzerine bir deneme: Aragon'un" Le Paysan de Paris"(Paris köylüsü) adlı yapıtı üzerine bir örnekleme. İzmir: Matbaa Kavram.

Ulusal Tez Merkezi(2020).Erişim adresi: https://tez.yok.gov.tr/UlusalTezMerkezi/

Vitruvius, P. (2005). Vitruvius: mimarlık üzerine on kitap. (Çev. Suna Güven). Şevki Vanlı Mimarlık Vakfı Yayınları. 


\section{Ekler}

EK:1 1987 - Ağustos 2020 Tarihleri Arasında Mimarlık ve Edebiyat İlişkisi Bağlamında Ulusal Tez Merkezi'nden Taranan Yüksek Lisans/Doktora Tezleri Listesi

\begin{tabular}{|c|c|c|c|c|c|c|c|c|c|}
\hline $\begin{array}{l}\mathbf{N} \\
\mathbf{o}\end{array}$ & Tezin Adı & Tezin Yazarı & $\begin{array}{l}\text { Tez } \\
\text { Danışmanı }\end{array}$ & Yil & Tür & Üniversite & Enstitü & $\begin{array}{l}\text { Anabilim } \\
\text { Dalı }\end{array}$ & Anahtar Kelimeler \\
\hline 1. & $\begin{array}{l}\text { Ahmet Midhat Efendi'nin Ro- } \\
\text { manlarında Mekân }\end{array}$ & Cengiz Ketene & - & 1987 & $\mathrm{DR}$ & $\begin{array}{l}\text { Atatürk } \\
\text { Üniversitesi }\end{array}$ & SBE & $\begin{array}{l}\text { Türk Dili ve } \\
\text { Edeb. }\end{array}$ & $\begin{array}{l}\text { Ahmet Midhat Efendi, } \\
\text { Mekân, Roman }\end{array}$ \\
\hline 2. & $\begin{array}{l}\text { Gravür ve Seyahatnamelerde } \\
\text { Anitsal Yapilarıyla İstanbul (18. } \\
\text { Yüzyıl Sonu ve 19. Yüzyıl) }\end{array}$ & Necla Arslan & $\begin{array}{l}\text { Semra Ger- } \\
\text { maner }\end{array}$ & 1992 & $\mathrm{DR}$ & $\begin{array}{l}\text { Mimar Si- } \\
\text { nan Güzel } \\
\text { Sanatlar } \\
\text { Üniversitesi } \\
\end{array}$ & SBE & Sanat Tarihi & $\begin{array}{l}\text { 18. yy, 19. yy, Gravür, Seya- } \\
\text { hatname, İstanbul }\end{array}$ \\
\hline 3. & $\begin{array}{l}\text { Mimari Bir Dilin Biçim Grameri } \\
\text { Analizi ve Bilgisayar Ortamında } \\
\text { Sunumu }\end{array}$ & $\begin{array}{l}\text { Eda Veliba- } \\
\text { şoğlu }\end{array}$ & $\begin{array}{l}\text { Gülen Çağ- } \\
\text { daş }\end{array}$ & 1995 & YL & $\begin{array}{l}\text { İstanbul } \\
\text { Teknik Üni- } \\
\text { versitesi } \\
\end{array}$ & FBE & Mimarlık & $\begin{array}{l}\text { Bilgisayar Destekli Tasarım, } \\
\text { Mimari Dil, Mimari Tasarım }\end{array}$ \\
\hline 4. & $\begin{array}{l}\text { Michael A. H. Ende'nin Momo ve } \\
\text { Peyami Safa'nın Matmazel Nora- } \\
\text { liya'nın Koltuğu Eserlerinin An- } \\
\text { latım Teknikleri, Mekân ve Za- } \\
\text { man Bakımından Mukayesesi }\end{array}$ & Emin Akkaya & Arif Ünal & 1996 & YL & $\begin{array}{l}\text { Yüzüncü } \\
\text { Yll Üniver- } \\
\text { sitesi }\end{array}$ & SBE & $\begin{array}{l}\text { Alman Dili } \\
\text { ve Edeb. }\end{array}$ & $\begin{array}{l}\text { Alman Dili ve Edebiyatı, } \\
\text { Türk Dili ve Edebiyatı, Mic- } \\
\text { hael Ende, Karşılaştırmalı } \\
\text { edebiyat, Peyami Safa }\end{array}$ \\
\hline 5. & $\begin{array}{l}\text { Sevinç Çokum 'un Hikâye ve Ro- } \\
\text { manlarında Zaman, Mekân ve } \\
\text { İnsan Unsuru, I. Cilt }\end{array}$ & Ayfer Yılmaz & Sadık Tural & 1997 & $\mathrm{DR}$ & $\begin{array}{l}\text { Gazi Üni- } \\
\text { versitesi }\end{array}$ & SBE & $\begin{array}{l}\text { Türk Dili ve } \\
\text { Edeb. }\end{array}$ & $\begin{array}{l}\text { Hikâye, Kadın yazarlar, Ka- } \\
\text { dın, Mekân Roman Zaman, } \\
\text { Sevinç Çokum, İnsan }\end{array}$ \\
\hline 6. & $\begin{array}{l}\text { Sait Faik Abasıyanık'ın Hikâye- } \\
\text { lerinde Mekân }\end{array}$ & $\begin{array}{l}\text { Gülnaz Çeti- } \\
\text { noğlu }\end{array}$ & Coşkun Ak & 1997 & YL & $\begin{array}{l}\text { Uludağ } \\
\text { Üniversitesi }\end{array}$ & SBE & $\begin{array}{l}\text { Türk Dili ve } \\
\text { Edeb. }\end{array}$ & $\begin{array}{l}\text { Sait Faik Abasıyanık, Hikâye, } \\
\text { Mekân }\end{array}$ \\
\hline 7. & $\begin{array}{l}\text { Romanlarda Temsil Edildiği Bi- } \\
\text { çimiyle Edebiyatta Kurgulanmış } \\
\text { Mekân Bir İnceleme Çalışması: } \\
\text { Kara Kitap, Orhan Pamuk } \\
\end{array}$ & Beyhan Bolak & $\begin{array}{l}\text { Celal Abdi } \\
\text { Güzer }\end{array}$ & 2000 & YL & $\begin{array}{l}\text { Orta Doğu } \\
\text { Teknik Üni- } \\
\text { versitesi }\end{array}$ & FBE & Mimarlık & $\begin{array}{l}\text { Kara Kitap, Mekân, Orhan } \\
\text { Pamuk, Roman }\end{array}$ \\
\hline 8. & $\begin{array}{l}\text { 1923-1950 Yılları Ankara'sına Mi- } \\
\text { mari ve Edebi Bir Bakış }\end{array}$ & Emel Dinçer & $\begin{array}{l}\text { İnci Asla- } \\
\text { noğlu }\end{array}$ & 2000 & YL & $\begin{array}{l}\text { Orta Doğu } \\
\text { Teknik Üni- } \\
\text { versitesi }\end{array}$ & SBE & Mimarlık & $\begin{array}{l}\text { Ankara, Edebiyat, Konut, Mi- } \\
\text { mari Özellikler, Mimarlık Ta- } \\
\text { rihi }\end{array}$ \\
\hline
\end{tabular}




\begin{tabular}{|c|c|c|c|c|c|c|c|c|c|}
\hline $\begin{array}{l}\mathbf{N} \\
\mathbf{o}\end{array}$ & Tezin Adı & Tezin Yazarı & $\begin{array}{l}\text { Tez } \\
\text { Danışmanı }\end{array}$ & Yil & Tür & Üniversite & Enstitü & $\begin{array}{l}\text { Anabilim } \\
\text { Dalı }\end{array}$ & Anahtar Kelimeler \\
\hline 9. & $\begin{array}{l}\text { Ahmet Hamdi Tanpınar'ın yazı- } \\
\text { larında İstanbul'daki mimarlık } \\
\text { yapıtlarının değerlendirilmesi }\end{array}$ & Nevin Algül & $\begin{array}{l}\text { Metin } \\
\text { Sözen }\end{array}$ & 2001 & YL & $\begin{array}{l}\text { İstanbul } \\
\text { Teknik Üni- } \\
\text { versitesi }\end{array}$ & SBE & Sanat Tarihi & $\begin{array}{l}\text { Mimari Eserler, Ahmet } \\
\text { Hamdi Tanpınar, İstanbul }\end{array}$ \\
\hline 10. & $\begin{array}{l}\text { Bilim-Kurgu Edebiyatında } \\
\text { Ütopya ve Mimarlık İlişkisi }\end{array}$ & Evren Yalım & $\begin{array}{l}\text { Hülya } \\
\text { Yürekli }\end{array}$ & 2002 & YL & $\begin{array}{l}\text { İstanbul } \\
\text { Teknik Üni- } \\
\text { versitesi }\end{array}$ & FBE & Mimarlık & $\begin{array}{l}\text { Bilim Kurgu, Mimarlık, } \\
\text { Ütopya }\end{array}$ \\
\hline 11. & $\begin{array}{l}\text { Erken Cumhuriyet Dönemi'nde } \\
\text { Ankara Kenti Mekânsal Dönü- } \\
\text { şümlerinin Ankara Romanı Üze- } \\
\text { rinden Değerlendirilmesi }\end{array}$ & $\begin{array}{l}\text { Didem Ertuğ- } \\
\text { rul A. }\end{array}$ & $\begin{array}{l}\text { Dürrin Süer } \\
\text { Kılıç }\end{array}$ & 2003 & YL & $\begin{array}{l}\text { Dokuz Ey- } \\
\text { lül Üniver- } \\
\text { sitesi }\end{array}$ & FBE & Mimarlık & $\begin{array}{l}\text { Erken Cumhuriyet Dönemi, } \\
\text { Batılllaşma/Modernleşme, } \\
\text { Türk Romanı, Ankara, Yakup } \\
\text { Kadri Karaosmanoğlu }\end{array}$ \\
\hline 12. & $\begin{array}{l}\text { Sabahattin Ali'nin Roman ve } \\
\text { Hikâyelerinde Mekân ve } \\
\text { Mekânın Anlatımı }\end{array}$ & Metin Polat & Şerif Aktaş & 2003 & YL & $\begin{array}{l}\text { Gazi Üni- } \\
\text { versitesi }\end{array}$ & SBE & $\begin{array}{l}\text { Türk Dili ve } \\
\text { Edeb. }\end{array}$ & $\begin{array}{l}\text { Türk Dili ve Edebiyat1, } \\
\text { Hikâye, Mekân, Roman, Sa- } \\
\text { bahattin Ali, Yeni Türk Edebi- } \\
\text { yatı }\end{array}$ \\
\hline 13. & $\begin{array}{l}\text { Kemal Tahir'in Köy Romanla- } \\
\text { rında Mekân }\end{array}$ & Özgür İldeş & Şerif Aktaş & 2003 & YL & $\begin{array}{l}\text { Gazi Üni- } \\
\text { versitesi }\end{array}$ & SBE & $\begin{array}{l}\text { Türk Dili ve } \\
\text { Edeb. }\end{array}$ & $\begin{array}{l}\text { Kemal Tahir, Köy, Roman, } \\
\text { Yeni Türk Edebiyatı }\end{array}$ \\
\hline 14. & Behçet Necatigil ve Şiirin Ev Hali & $\begin{array}{l}\text { Şehnaz Şişma- } \\
\text { noğlu }\end{array}$ & $\begin{array}{l}\text { Orhan } \\
\text { Tekelioğlu }\end{array}$ & 2003 & YL & $\begin{array}{l}\text { Bilkent Üni- } \\
\text { versitesi }\end{array}$ & Eko ve SBE & $\begin{array}{l}\text { Türk Dili ve } \\
\text { Edeb. }\end{array}$ & $\begin{array}{l}\text { Ev, Behçet Necatigil, Türk } \\
\text { Edebiyatı, Türk Şiiri, Şiir }\end{array}$ \\
\hline 15. & $\begin{array}{l}\text { Erken Türk Romanında Fiziksel } \\
\text { Çevre Sorunsalı }\end{array}$ & $\begin{array}{l}\text { Hayal Meriç } \\
\text { Uğraş }\end{array}$ & $\begin{array}{l}\text { Uğur } \\
\text { Tanyeli }\end{array}$ & 2003 & YL & $\begin{array}{l}\text { Yıldız Tek- } \\
\text { nik Üniver- } \\
\text { sitesi } \\
\end{array}$ & FBE & Mimarlık & $\begin{array}{l}\text { Erken Türk Roman,, Fiziksel } \\
\text { Çevre, Mekân, Roman }\end{array}$ \\
\hline 16. & $\begin{array}{l}\text { Orhan Pamuk Romaninda At- } \\
\text { mosfer }\end{array}$ & $\begin{array}{l}\text { Ayşegül } \\
\text { Uğurlu }\end{array}$ & Atilla Yücel & 2003 & YL & $\begin{array}{l}\text { İstanbul } \\
\text { Teknik Üni- } \\
\text { versitesi }\end{array}$ & FBE & Mimarlık & $\begin{array}{l}\text { Orhan Pamuk, Roman, At- } \\
\text { mosfer }\end{array}$ \\
\hline 17. & $\begin{array}{l}\text { Yaşar Kemal'in İstanbul'una } \\
\text { Çevreci Bir Yolculuk }\end{array}$ & $\begin{array}{l}\text { Günil Özlem } \\
\text { Ayaydın }\end{array}$ & $\begin{array}{l}\text { Süha } \\
\text { Oğuzerten }\end{array}$ & 2003 & YL & $\begin{array}{l}\text { Bilkent Üni- } \\
\text { versitesi }\end{array}$ & Eko ve SBE & $\begin{array}{l}\text { Türk Dili ve } \\
\text { Edeb. }\end{array}$ & $\begin{array}{l}\text { İstanbul, Deniz, Çevreci Eleş- } \\
\text { tiri, Yabancilaşma }\end{array}$ \\
\hline 18. & $\begin{array}{l}\text { Türkiye Masallarında Toplumsal } \\
\text { Cinsiyet ve Mekân İlişkisi }\end{array}$ & Evrim Ölçer & $\begin{array}{l}\text { Talat } \\
\text { Halman }\end{array}$ & 2003 & YL & $\begin{array}{l}\text { Bilkent Üni- } \\
\text { versitesi }\end{array}$ & SBE & $\begin{array}{l}\text { Türk Dili ve } \\
\text { Edeb. }\end{array}$ & $\begin{array}{l}\text { Cinsel Kimlik, Gelenek, Ma- } \\
\text { sal, Mekân, Türk Masalları }\end{array}$ \\
\hline
\end{tabular}


Mimarlık ve Edebiyat İlişkisine Dair Yapılmış Akademik Çalışmaların Bir Sınıflandırması

\begin{tabular}{|c|c|c|c|c|c|c|c|c|c|}
\hline $\begin{array}{l}\mathbf{N} \\
\mathbf{o}\end{array}$ & Tezin Adı & Tezin Yazarı & $\begin{array}{l}\text { Tez } \\
\text { Danışmanı }\end{array}$ & Yil & Tür & Üniversite & Enstitü & $\begin{array}{l}\text { Anabilim } \\
\text { Dalı }\end{array}$ & Anahtar Kelimeler \\
\hline 19. & $\begin{array}{l}\text { Kent Mekânının Dönüşümünde } \\
\text { Kullanıc1-Kent Etkileşiminin } \\
\text { (Deneyiminin) Edebi Metinler } \\
\text { Üzerinden İrdelenmesi } \\
\end{array}$ & Bahar Ünlü & $\begin{array}{l}\text { Ferhan } \\
\text { Yürekli }\end{array}$ & 2004 & YL & $\begin{array}{l}\text { İstanbul } \\
\text { Teknik Üni- } \\
\text { versitesi }\end{array}$ & FBE & Mimarlık & $\begin{array}{l}\text { İnsan-Kent İlişkisi, Kentsel } \\
\text { Deneyimleme, Beyoğlu, } \\
\text { Edebi Metin }\end{array}$ \\
\hline 20. & $\begin{array}{l}\text { Altı Türk Romanında Mekânsal } \\
\text { Öge ve Mekânsal Davranış İnce- } \\
\text { lemesi }\end{array}$ & $\begin{array}{l}\text { Suna Arslan } \\
\mathrm{K} \text {. }\end{array}$ & $\begin{array}{l}\text { Cahit } \\
\text { Kavcar }\end{array}$ & 2004 & DR & $\begin{array}{l}\text { Ankara } \\
\text { Üniversitesi }\end{array}$ & EBE & $\begin{array}{l}\text { Güzel Sa- } \\
\text { natlar Eği- } \\
\text { timi }\end{array}$ & $\begin{array}{lrr}\text { Roman, } & \text { Mekânsal } & \text { Öğe, } \\
\text { Mekânsal } & \text { Davranış, İçerik } \\
\text { Analizi } & & \end{array}$ \\
\hline 21. & $\begin{array}{l}\text { Cumhuriyet Dönemi Türk Ro- } \\
\text { manında Modernizmin Yeri }\end{array}$ & Hasan Yürek & $\begin{array}{l}\text { Nilgün } \\
\text { Çıblak }\end{array}$ & 2005 & $\mathrm{YL}$ & $\begin{array}{l}\text { Mersin Üni- } \\
\text { versitesi }\end{array}$ & SBE & $\begin{array}{l}\text { Türk Dili ve } \\
\text { Edeb. }\end{array}$ & $\begin{array}{l}\text { Roman, Türk Romani, Mo- } \\
\text { dernist Roman, Modernizm }\end{array}$ \\
\hline 22. & $\begin{array}{l}\text { Halide Edib Adıvar'ın Son Dö- } \\
\text { nem Romanlarında İstanbul'da } \\
\text { Gündelik Hayat ve Müzik }\end{array}$ & $\begin{array}{l}\text { Damla Erle- } \\
\text { vent }\end{array}$ & $\begin{array}{l}\text { Mehmet } \\
\text { Kalpaklı }\end{array}$ & 2005 & $\mathrm{YL}$ & $\begin{array}{l}\text { Bilkent Üni- } \\
\text { versitesi }\end{array}$ & Eko.ve SBE & $\begin{array}{l}\text { Türk Dili ve } \\
\text { Edeb. }\end{array}$ & $\begin{array}{l}\text { Halide Edip Adıvar, İstanbul, } \\
\text { Gündelik Hayat }\end{array}$ \\
\hline 23. & $\begin{array}{l}\text { Sâmiha Ayverdi'nin Eserlerinde } \\
\text { Üç Temel Mekân: Konak, Köşk } \\
\text { ve Yalı }\end{array}$ & Selami Alan & $\begin{array}{l}\text { Muharrem } \\
\text { Dayanç }\end{array}$ & 2005 & $\mathrm{YL}$ & $\begin{array}{l}\text { Eskişehir } \\
\text { Osmangazi } \\
\text { Üniversitesi }\end{array}$ & SBE & $\begin{array}{l}\text { Türk Dili ve } \\
\text { Edeb. }\end{array}$ & $\begin{array}{l}\text { Samiha Ayverdi, Konak, } \\
\text { Köşk, Mekân, Mekânsal Yapı- } \\
\text { lar, Mekânsal Özellikler, Ro- } \\
\text { man, Türk Edebiyatı, Türk } \\
\text { Romanı, Yalı }\end{array}$ \\
\hline 24. & $\begin{array}{l}\text { Orhan Kemal'in Gurbet Kuşları } \\
\text { ve Latife Tekin'in Sevgili Arsız } \\
\text { Ölüm Romanlarında Köyden } \\
\text { Kente Göç ve Yoksulluk }\end{array}$ & $\begin{array}{l}\text { Turgay Gü- } \\
\text { meli }\end{array}$ & $\begin{array}{l}\text { Ayşe Melda } \\
\text { Üner }\end{array}$ & 2006 & $\mathrm{YL}$ & $\begin{array}{l}\text { Yeditepe } \\
\text { Üniversitesi }\end{array}$ & SBE & $\begin{array}{l}\text { Türk Dili ve } \\
\text { Edeb. }\end{array}$ & $\begin{array}{l}\text { Kentlileşme, Yoksulluk, Ro- } \\
\text { man, Orhan Kemal, Latife Te- } \\
\text { kin }\end{array}$ \\
\hline 25. & $\begin{array}{l}\text { James Joyces'un Kısa Romanında } \\
\text { Dublin'in Zaman-Mekân İliş̧kisi }\end{array}$ & $\begin{array}{l}\text { Fatma Betül } \\
\text { Haksal }\end{array}$ & $\begin{array}{l}\text { Petru } \\
\text { Golban }\end{array}$ & 2006 & YL & $\begin{array}{l}\text { Dumlupi- } \\
\text { nar Üniver- } \\
\text { sitesi }\end{array}$ & SBE & $\begin{array}{l}\text { İngiliz Dili } \\
\text { ve Edeb. }\end{array}$ & $\begin{array}{l}\text { Kronotop, James Joyce, Sos- } \\
\text { yal Hayat, Anlatı }\end{array}$ \\
\hline 26. & $\begin{array}{l}\text { Mimarlık ve Bilimkurgu Edebi- } \\
\text { yatında Mekân Okumaları }\end{array}$ & $\begin{array}{l}\text { Pelin Melisa } \\
\text { Somer }\end{array}$ & $\begin{array}{l}\text { Arzu } \\
\text { Erdem }\end{array}$ & 2006 & YL & $\begin{array}{l}\text { İstanbul } \\
\text { Teknik Üni- } \\
\text { versitesi }\end{array}$ & FBE & Mimarlık & Siberuzay, Ütopya \\
\hline 27. & $\begin{array}{l}\text { Sait Faik Abasıyanık'ın Eserle- } \\
\text { rinde Mekân Olarak İstanbul }\end{array}$ & $\begin{array}{l}\text { Yeşim Özde- } \\
\text { mir }\end{array}$ & Kâzım Yetiş & 2006 & $\mathrm{YL}$ & $\begin{array}{l}\text { İstanbul } \\
\text { Üniversitesi }\end{array}$ & SBE & $\begin{array}{l}\text { Türk Dili ve } \\
\text { Edeb. }\end{array}$ & İstanbul \\
\hline 28. & $\begin{array}{l}\text { Elif Şafak'ın Romanlarında } \\
\text { Mekân Ögesinin Zaman-Kişi ve } \\
\text { Olay Bağlamında İncelenmesi }\end{array}$ & Basri Yılmaz & $\begin{array}{l}\text { Müzeyyen } \\
\text { Buttanrı }\end{array}$ & 2007 & $\mathrm{YL}$ & $\begin{array}{l}\text { Eskişehir } \\
\text { Osmangazi } \\
\text { Üniversitesi }\end{array}$ & SBE & $\begin{array}{l}\text { Türk Dili ve } \\
\text { Edeb. }\end{array}$ & $\begin{array}{l}\text { Elif Şafak, Roman, Mekân, } \\
\text { Zaman }\end{array}$ \\
\hline
\end{tabular}




\begin{tabular}{|c|c|c|c|c|c|c|c|c|c|}
\hline $\begin{array}{l}\mathbf{N} \\
\mathbf{o}\end{array}$ & Tezin Adı & Tezin Yazarı & $\begin{array}{l}\text { Tez } \\
\text { Danışmanı }\end{array}$ & Yil & Tür & Üniversite & Enstitü & $\begin{array}{l}\text { Anabilim } \\
\text { Dalı }\end{array}$ & Anahtar Kelimeler \\
\hline 29. & Türk Romanında Mekân & Ferda Zambak & $\begin{array}{l}\text { Vedat } \\
\text { Kurukafa }\end{array}$ & 2007 & YL & $\begin{array}{l}\text { Muğla Üni- } \\
\text { versitesi }\end{array}$ & SBE & $\begin{array}{l}\text { Türk Dili ve } \\
\text { Edeb. }\end{array}$ & $\begin{array}{l}\text { Türk Romanı, Mekân, Görsel- } \\
\text { lik, Somutlaştırma, Çağrışım, } \\
\text { Gerçekçilik. }\end{array}$ \\
\hline 30. & Türk Edebiyatında Taşra & Diler Bulut & $\begin{array}{l}\text { Meral } \\
\text { Özbek }\end{array}$ & 2007 & YL & $\begin{array}{l}\text { Mimar Si- } \\
\text { nan Güzel } \\
\text { Sanatlar } \\
\text { Üniversitesi } \\
\end{array}$ & SBE & Sosyoloji & $\begin{array}{l}\text { Taşra, Merkez, Kent, Modern- } \\
\text { leşme, Edebiyat }\end{array}$ \\
\hline 31. & $\begin{array}{l}\text { Tanzimat Romaninda Kamusal } \\
\text { Alan ve Serbest Zaman Etkinlik- } \\
\text { leri }\end{array}$ & $\begin{array}{l}\text { Ayşegül Utku } \\
\text { Günaydın }\end{array}$ & $\begin{array}{l}\text { Laurent } \\
\text { Mignon }\end{array}$ & 2007 & YL & $\begin{array}{l}\text { Bilkent Üni- } \\
\text { versitesi }\end{array}$ & Eko ve SBE & $\begin{array}{l}\text { Türk Dili ve } \\
\text { Edeb. }\end{array}$ & $\begin{array}{l}\text { Tanzimat Romanı, Batıl1- } \\
\text { laşma, Kamusal Alan, Serbest } \\
\text { Zaman Etkinlikleri }\end{array}$ \\
\hline 32. & $\begin{array}{l}\text { Tanzimat Dönemi Türk Roman- } \\
\text { larında Beyoğlu }\end{array}$ & Emine Uzun & Fatih Andı & 2007 & YL & $\begin{array}{l}\text { İstanbul } \\
\text { Üniversitesi }\end{array}$ & SBE & $\begin{array}{l}\text { Türk Dili ve } \\
\text { Edeb. }\end{array}$ & $\begin{array}{l}\text { Tanzimat Romanı, Beyoğlu, } \\
\text { Gündelik Hayat, Mekân, İn- } \\
\text { san }\end{array}$ \\
\hline 33. & $\begin{array}{l}\text { Seksenler İstanbul'u Kentsel Söy- } \\
\text { lemini Popüler Yazılı Medya } \\
\text { Üzerinden Okumak }\end{array}$ & $\begin{array}{l}\text { Funda Uz } \\
\text { Sönmez }\end{array}$ & Atilla Yücel & 2007 & DR & $\begin{array}{l}\text { İstanbul } \\
\text { Teknik Üni- } \\
\text { versitesi }\end{array}$ & FBE & Mimarlık & $\begin{array}{l}\text { Küreselleşme, Nostalji, Popü- } \\
\text { ler kültür, İstanbul }\end{array}$ \\
\hline 34. & $\begin{array}{l}\text { Nazım Hikmet ve Attila İlhan Şi- } \\
\text { irinde Paris İmgesi }\end{array}$ & $\begin{array}{l}\text { Pelin Ekşi Al- } \\
\text { tay }\end{array}$ & $\begin{array}{l}\text { Nedret Ku- } \\
\text { ran Bur- } \\
\text { çoğlu }\end{array}$ & 2007 & YL & $\begin{array}{l}\text { Yeditepe } \\
\text { Üniversitesi }\end{array}$ & SBE & $\begin{array}{l}\text { Türk Dili ve } \\
\text { Edeb. }\end{array}$ & $\begin{array}{l}\text { Alımlama Kuramı, Yorum Bi- } \\
\text { lim, Görüngübilim, Attila İl- } \\
\text { han, Nazım Hikmet, Paris }\end{array}$ \\
\hline 35. & $\begin{array}{l}\text { Mimarlık ve Bilim Kurgu Edebi- } \\
\text { yatı Arakesitinde J. G. Ballard'ı } \\
\text { Okumak }\end{array}$ & $\begin{array}{l}\text { Zeynep Tuna } \\
\text { Ultav }\end{array}$ & $\begin{array}{l}\text { T. Nur Çağ- } \\
\text { lar }\end{array}$ & 2008 & $\mathrm{DR}$ & $\begin{array}{l}\text { Gazi Üni- } \\
\text { versitesi }\end{array}$ & FBE & Mimarlık & $\begin{array}{l}\text { Mimarlık Söylemi, Bilim } \\
\text { Kurgu, Edebiyat, Ballard, Di- } \\
\text { siplinlerarasılık, Metinsel Çö- } \\
\text { zümleme, Distopya }\end{array}$ \\
\hline 36. & $\begin{array}{l}\text { Ahmet Mithat Efendi'nin Letâîf-İ } \\
\text { Rivâyât Adlı Eserinin "Edebiyat } \\
\text { Coğrafya Merkezli" İncelenmesi }\end{array}$ & Neşe Bilgiç & $\begin{array}{l}\text { Ayşe Emel } \\
\text { Kefeli }\end{array}$ & 2008 & YL & $\begin{array}{l}\text { Marmara } \\
\text { Üniversitesi }\end{array}$ & Türkiyat & $\begin{array}{l}\text { Türk Dili ve } \\
\text { Edeb. }\end{array}$ & Coğrafya, Doğu, Batı, seyahat \\
\hline 37. & $\begin{array}{l}\text { Cumhuriyet Dönemi Hikâyele- } \\
\text { rinde Anadolu (1923-1950) }\end{array}$ & Polat Sel & $\begin{array}{l}\text { Özcan Ay- } \\
\text { gün }\end{array}$ & 2008 & YL & $\begin{array}{l}\text { Trakya Üni- } \\
\text { versitesi }\end{array}$ & SBE & $\begin{array}{l}\text { Türk Dili ve } \\
\text { Edeb. }\end{array}$ & $\begin{array}{l}\text { Anadolu, Mekân, Cumhuri- } \\
\text { yet Dönemi, Yazar, Hikâye }\end{array}$ \\
\hline 38. & $\begin{array}{l}\text { Nedim Gürsel'in Öykü ve Ro- } \\
\text { manlarında Kent ve Kadın }\end{array}$ & Mustafa Bal & $\begin{array}{l}\text { Bedri } \\
\text { Aydoğan }\end{array}$ & 2008 & YL & $\begin{array}{l}\text { Çukurova } \\
\text { Üniversitesi }\end{array}$ & SBE & $\begin{array}{l}\text { Türk Dili ve } \\
\text { Edeb. }\end{array}$ & $\begin{array}{l}\text { Nedim Gürsel, Kent, Kadın, } \\
\text { Öykü, Roman }\end{array}$ \\
\hline
\end{tabular}




\begin{tabular}{|c|c|c|c|c|c|c|c|c|c|}
\hline $\begin{array}{l}\mathbf{N} \\
\mathbf{o}\end{array}$ & Tezin Adı & Tezin Yazarı & $\begin{array}{l}\text { Tez } \\
\text { Danışmanı }\end{array}$ & Yil & Tür & Üniversite & Enstitü & $\begin{array}{c}\text { Anabilim } \\
\text { Dalı }\end{array}$ & Anahtar Kelimeler \\
\hline 39. & $\begin{array}{l}\text { Roman Kent Berlin. Alman ve } \\
\text { Türk Edebiyatında Kent İmge- } \\
\text { sini Yeniden Anlamlandıran Ka- } \\
\text { dın Yazarlar: Keun, Özdamar, } \\
\text { Özlü }\end{array}$ & Lale Dayıoğlu & $\begin{array}{l}\text { Meral } \\
\text { Oraliş }\end{array}$ & 2009 & $\mathrm{YL}$ & $\begin{array}{l}\text { İstanbul } \\
\text { Üniversitesi }\end{array}$ & SBE & $\begin{array}{l}\text { Alman Dili } \\
\text { ve Edeb. }\end{array}$ & $\begin{array}{l}\text { Alman edebiyatı, Edebiyat, } \\
\text { Kadın Yazarlar, Kent Kimliği, } \\
\text { Kentsel Mekân, Keun, Irm- } \\
\text { gard, Türk edebiyatı, Emine } \\
\text { Sevgi Özdamar, Tezer Özlü }\end{array}$ \\
\hline 40. & $\begin{array}{l}\text { Modernleşme Sürecinde İktidar- } \\
\text { Taşra İlişkileri: Türk Edebiya- } \\
\text { tında 'Taşra' }\end{array}$ & $\begin{array}{l}\text { Hatice Sevgi } \\
\text { Zengin }\end{array}$ & $\begin{array}{l}\text { Ahmet } \\
\text { Çiğdem }\end{array}$ & 2009 & $\mathrm{DR}$ & $\begin{array}{l}\text { Gazi Üni- } \\
\text { versitesi }\end{array}$ & SBE & $\begin{array}{l}\text { Türk Dili ve } \\
\text { Edeb. }\end{array}$ & $\begin{array}{l}\text { Modernite, Modernleşme, Si- } \\
\text { yasi iktidar, Taşra, Türk ede- } \\
\text { biyatı, İktidar, İktidar ilişki- } \\
\text { leri }\end{array}$ \\
\hline 41. & $\begin{array}{l}\text { Türk Romanında Kent ve Kentli- } \\
\text { leşme Eğilimleri }\end{array}$ & $\begin{array}{l}\text { Aziz Behlül } \\
\text { Akboğa }\end{array}$ & $\begin{array}{l}\text { Köksal } \\
\text { Alver }\end{array}$ & 2009 & YL & $\begin{array}{l}\text { Selçuk Üni- } \\
\text { versitesi }\end{array}$ & SBE & Sosyoloji & $\begin{array}{l}\text { Kent, Kentleşme, Kentli- } \\
\text { leşme, Roman. }\end{array}$ \\
\hline 42. & $\begin{array}{l}\text { Peyami Safa'nın Romanlarında } \\
\text { Modernleşme ve Mekân }\end{array}$ & $\begin{array}{l}\text { Süreyya Elif } \\
\text { Aksoy }\end{array}$ & $\begin{array}{l}\text { Laurent } \\
\text { Mignon }\end{array}$ & 2009 & $\mathrm{DR}$ & $\begin{array}{l}\text { Bilkent Üni- } \\
\text { versitesi }\end{array}$ & Eko ve SBE & $\begin{array}{l}\text { Türk Dili ve } \\
\text { Edeb. }\end{array}$ & $\begin{array}{l}\text { Peyami Safa, modernlik, kent, } \\
\text { sosyal uzam, gündelik hayat, } \\
\text { muhafazakârlık, roman }\end{array}$ \\
\hline 43. & $\begin{array}{l}\text { On Dokuzuncu Yüzyıl İstan- } \\
\text { bul'unda Kamusal Yaşam ve } \\
\text { Mekânlarının Tanzimat Roman- } \\
\text { ları Üzerinden Okunması }\end{array}$ & $\begin{array}{l}\text { Ayşe Nur Şe- } \\
\text { nel }\end{array}$ & Ela Çil & 2010 & YL & $\begin{array}{l}\text { İzmir Yük- } \\
\text { sek Tekno- } \\
\text { loji Ensti- } \\
\text { tüsü }\end{array}$ & FBE & Mimarlık & $\begin{array}{l}\text { Tanzimat Romanı, Mekânsal } \\
\text { Analiz, İstanbul, Kamusal Ya- } \\
\text { şam }\end{array}$ \\
\hline 44. & $\begin{array}{l}\text { Halit Ziya Uşaklıgil'in Romanla- } \\
\text { rında Anne-Mekân Algisı }\end{array}$ & Serdar Şen & Fatih Arslan & 2010 & $\mathrm{YL}$ & $\begin{array}{l}\text { Frrat Üni- } \\
\text { versitesi }\end{array}$ & SBE & $\begin{array}{l}\text { Türk Dili ve } \\
\text { Edeb. }\end{array}$ & $\begin{array}{l}\text { Halit Ziya Uşaklıgil, Roman, } \\
\text { Anne, Mekân }\end{array}$ \\
\hline 45. & $\begin{array}{l}\text { Edebi Eserlerde Betimlenmiş Mi- } \\
\text { mari Mekânların Sinemada Tem- } \\
\text { sili }\end{array}$ & Gamze Tükel & $\begin{array}{l}\text { Orhan Hac1- } \\
\text { hasanoğlu }\end{array}$ & 2010 & YL & $\begin{array}{l}\text { İstanbul } \\
\text { Teknik Üni- } \\
\text { versitesi } \\
\end{array}$ & FBE & Mimarlık & $\begin{array}{l}\text { Edebiyat, Göstergebilim, Mi- } \\
\text { mari, Sinema, Tasvir, Zaman- } \\
\text { Mekân }\end{array}$ \\
\hline 46. & $\begin{array}{l}\text { Kafkaesk Mekân: Franz Kafka } \\
\text { Edebiyatı Üzerinden Mekân } \\
\text { Okumaları }\end{array}$ & Burçe Gürsel & $\begin{array}{l}\text { Deniz } \\
\text { İncedayı }\end{array}$ & 2010 & YL & $\begin{array}{l}\text { Mimar Si- } \\
\text { nan Güzel } \\
\text { Sanatlar } \\
\text { Üniversitesi }\end{array}$ & FBE & Mimarlık & Franz Kafka, Mimari Mekân \\
\hline 47. & $\begin{array}{l}\text { Edebiyat ve Müze: Bir Roman ve } \\
\text { Müze Olarak Masumiyet Müzesi }\end{array}$ & Selmin Kuş & $\begin{array}{l}\text { Neşe } \\
\text { Yldıran }\end{array}$ & 2010 & YL & $\begin{array}{l}\text { Yeditepe } \\
\text { Üniversitesi }\end{array}$ & SBE & $\begin{array}{l}\text { Türk Dili ve } \\
\text { Edeb. }\end{array}$ & $\begin{array}{l}\text { Bellek, Karşılaştırmalı Edebi- } \\
\text { yat, Masumiyet Müzesi, } \\
\text { Mekân, Müzecilik, Müze, } \\
\text { Nesne, Orhan Pamuk, Ro- } \\
\text { man, Türk Romanı, Zaman }\end{array}$ \\
\hline
\end{tabular}




\begin{tabular}{|c|c|c|c|c|c|c|c|c|c|}
\hline $\begin{array}{l}\mathbf{N} \\
\mathbf{o}\end{array}$ & Tezin Adı & Tezin Yazarı & $\begin{array}{l}\text { Tez } \\
\text { Danışmanı }\end{array}$ & Yil & Tür & Üniversite & Enstitü & $\begin{array}{l}\text { Anabilim } \\
\text { Dalı }\end{array}$ & Anahtar Kelimeler \\
\hline 48. & $\begin{array}{l}\text { Türk Romanında Kentleşme ve } \\
\text { Kentlileşme: 1950-1980 }\end{array}$ & Servet Tiken & $\begin{array}{l}\text { Erdoğan } \\
\text { Erbay }\end{array}$ & 2011 & DR & $\begin{array}{l}\text { Atatürk } \\
\text { Üniversitesi }\end{array}$ & SBE & $\begin{array}{l}\text { Türk Dili ve } \\
\text { Edeb. }\end{array}$ & $\begin{array}{l}\text { Türk Romanı, Toplumsal } \\
\text { Yapı, Kent, Kentleşme, Kent- } \\
\text { lileşme. }\end{array}$ \\
\hline 49. & $\begin{array}{l}\text { Aziyade, Arzular Şehri İstanbul } \\
\text { ve Kara Kitap Romanlarında Ri- } \\
\text { zomatik Arzu Mekânı Olarak İs- } \\
\text { tanbul }\end{array}$ & $\begin{array}{l}\text { Hatice Kara- } \\
\text { man }\end{array}$ & $\begin{array}{l}\text { Adriana } \\
\text { Luminita R. }\end{array}$ & 2011 & YL & $\begin{array}{l}\text { Yeditepe } \\
\text { Üniversitesi }\end{array}$ & SBE & $\begin{array}{l}\text { İngiliz Dili } \\
\text { ve Edeb. }\end{array}$ & $\begin{array}{l}\text { Rizom, Kültürel Melezlik, İs- } \\
\text { tanbul }\end{array}$ \\
\hline 50. & $\begin{array}{l}\text { Yaşar Kemal'de Göç Olgusu (Bir } \\
\text { Ada Hikâyesi I Fırat Suyu Kan } \\
\text { Akıyor Baksana, Bir Ada } \\
\text { Hikâyesi II Karıncanın Su İçtiği, } \\
\text { Bir Ada Hikâyesi III Tanyeri Ho- } \\
\text { rozları) }\end{array}$ & Ferudun Ay & $\begin{array}{l}\text { Hacer } \\
\text { Gülşen }\end{array}$ & 2011 & YL & $\begin{array}{l}\text { İstanbul } \\
\text { Kültür Üni- } \\
\text { versitesi }\end{array}$ & SBE & $\begin{array}{l}\text { Türk Dili ve } \\
\text { Edeb. }\end{array}$ & $\begin{array}{l}\text { Göç, Göç Olgusu, Mübadele, } \\
\text { Savaş, Kan Davası, Fakirlik, } \\
\text { İnsanlık, Vefa }\end{array}$ \\
\hline 51. & $\begin{array}{l}\text { Edip Cansever'in "Bezik Oyna- } \\
\text { yan Kadınlar" Şiirinde Zaman ve } \\
\text { Mekânın Poetikası }\end{array}$ & $\begin{array}{l}\text { Selcan Bayra- } \\
\text { moğlu }\end{array}$ & Murat Belge & 2011 & YL & $\begin{array}{l}\text { İstanbul } \\
\text { Bilgi Üni- } \\
\text { versitesi } \\
\end{array}$ & SBE & $\begin{array}{l}\text { Karş. Edebi- } \\
\text { yat }\end{array}$ & $\begin{array}{l}\text { Mekân, Obje, Zaman, Nesnel } \\
\text { Karşılık, İç Mekân/Dış } \\
\text { Mekân, Yalıtılmışlık }\end{array}$ \\
\hline 52. & $\begin{array}{l}\text { Mimarlık ve Bilimkurgu Edebi- } \\
\text { yatı Bağlamında Archigram'dan } \\
\text { ve Reeve'den Öğrendiklerimiz }\end{array}$ & Özlem Duran & $\begin{array}{l}\text { T. Nur } \\
\text { Çağlar }\end{array}$ & 2011 & YL & $\begin{array}{l}\text { Gazi Üni- } \\
\text { versitesi }\end{array}$ & FBE & Mimarlık & $\begin{array}{l}\text { Bilim Kurgu Edebiyat1, } \\
\text { Ütopya, Archigram, Philip } \\
\text { Reeve }\end{array}$ \\
\hline 53. & $\begin{array}{l}1920 \text { ve } 1950 \text { Arasında Yazılmış } \\
\text { Ters Ütopyalar Bağlamında Bas- } \\
\text { kın İdeolojinin Temsili Olarak } \\
\text { Yazınsal Mekânlar }\end{array}$ & $\begin{array}{l}\text { Rabia Çiğdem } \\
\text { Çavdar }\end{array}$ & $\begin{array}{l}\text { Güven } \\
\text { Arif Sargın }\end{array}$ & 2011 & YL & $\begin{array}{l}\text { Orta Doğu } \\
\text { Teknik Üni- } \\
\text { versitesi }\end{array}$ & FBE & Mimarlık & $\begin{array}{l}\text { Mimarlık, Yazınsal Mekân, } \\
\text { İdeoloji, Distopya, Ütopya, } \\
\text { Zamyatin, Huxley, Orwell, } \\
1920-1950\end{array}$ \\
\hline 54. & $\begin{array}{l}\text { Orhan Pamuk'un Romanlarında } \\
\text { Taşra }\end{array}$ & Erman Saygilı & $\begin{array}{l}\text { Osman } \\
\text { Konuk }\end{array}$ & 2012 & YL & $\begin{array}{l}\text { Afyon Ko- } \\
\text { catepe Üni- } \\
\text { versitesi }\end{array}$ & SBE & Sosyoloji & $\begin{array}{l}\text { Orhan Pamuk, Taşra, Moder- } \\
\text { nizm, Roman, Edebiyat Sos- } \\
\text { yolojisi }\end{array}$ \\
\hline 55. & $\begin{array}{l}\text { Servet-i Fünûn Romanında } \\
\text { Mekân }\end{array}$ & $\begin{array}{l}\text { Abdülhakim } \\
\text { Tuğluk }\end{array}$ & $\begin{array}{l}\text { Ebru Burcu } \\
\text { Yilmaz }\end{array}$ & 2012 & YL & $\begin{array}{l}\text { İnönü Üni- } \\
\text { versitesi }\end{array}$ & SBE & $\begin{array}{l}\text { Türk Dili ve } \\
\text { Edeb. }\end{array}$ & $\begin{array}{lrr}\text { Servet-İ Fünûn } & \text { Romanı, } \\
\text { Mekân, Mekânın } & \text { Poetiği, } \\
\text { Mekânsal, } & \text { Çevresel } \\
\text { Mekânlar, Ruhsal } & \text { Durumu } \\
\text { Yansıtan Mekânlar } & \\
\end{array}$ \\
\hline
\end{tabular}


Mimarlık ve Edebiyat İlişkisine Dair Yapılmış Akademik Çalışmaların Bir Sınıflandırması

\begin{tabular}{|c|c|c|c|c|c|c|c|c|c|}
\hline $\begin{array}{l}\mathbf{N} \\
\mathbf{o}\end{array}$ & Tezin Adı & Tezin Yazarı & $\begin{array}{l}\text { Tez } \\
\text { Danışmanı }\end{array}$ & Yil & Tür & Üniversite & Enstitü & $\begin{array}{l}\text { Anabilim } \\
\text { Dalı }\end{array}$ & Anahtar Kelimeler \\
\hline 56. & $\begin{array}{l}\text { Ursula Le Guin'in Mülküzler'i } \\
\text { Üzerinden Bir İnceleme: Kapita- } \\
\text { list Sistemin Üç İç Çelişkisi ve } \\
\text { Sisteme Karşı Çıkan Bir Mimarlı- } \\
\text { ğın Olabilirliği }\end{array}$ & Didem Cengiz & $\begin{array}{l}\text { Belkıs } \\
\text { Uluoğlu }\end{array}$ & 2012 & $\mathrm{YL}$ & $\begin{array}{l}\text { İstanbul } \\
\text { Teknik Üni- } \\
\text { versitesi }\end{array}$ & FBE & Mimarlık & $\begin{array}{l}\text { Ursula Le Guin, Ütopya, } \\
\text { Mülksüzler, Kapitalizm, Mi- } \\
\text { marlık }\end{array}$ \\
\hline 57. & $\begin{array}{l}\text { Cumhuriyet'e Kadar Türk Roma- } \\
\text { ninda Araplar ve Arap Coğraf- } \\
\text { yası }\end{array}$ & $\begin{array}{l}\text { Abdurrazek } \\
\text { Ahmed }\end{array}$ & Fatih Andı & 2012 & $\mathrm{DR}$ & $\begin{array}{l}\text { Fatih Sultan } \\
\text { Mehmet Va- } \\
\text { kıf Üniver- } \\
\text { sitesi }\end{array}$ & SBE & $\begin{array}{l}\text { Türk Dili ve } \\
\text { Edeb. }\end{array}$ & $\begin{array}{l}\text { Arap kültürü, Araplar, Ro- } \\
\text { man, Türk Romanı }\end{array}$ \\
\hline 58. & $\begin{array}{l}\text { Body, Space and Identity in Fran- } \\
\text { kenstein }\end{array}$ & Nilcan Dalgan & $\begin{array}{l}\text { Mehmet Ali } \\
\text { Çelikel }\end{array}$ & 2013 & $\mathrm{YL}$ & $\begin{array}{l}\text { Pamukkale } \\
\text { Üniversitesi }\end{array}$ & SBE & $\begin{array}{l}\text { İngiliz Dili } \\
\text { ve Edeb. }\end{array}$ & $\begin{array}{l}\text { Yeniden Yapılandırmacılık, } \\
\text { Beden, Mekân, Kimlik, Gotik, } \\
\text { Mary Shelley, Frankenstein } \\
\end{array}$ \\
\hline 59. & $\begin{array}{l}\text { Türk romaninda değişen coğ- } \\
\text { rafya (1923-1945) }\end{array}$ & Selda Uygur & $\begin{array}{l}\text { Ayşe Emel } \\
\text { Kefeli }\end{array}$ & 2013 & $\mathrm{DR}$ & $\begin{array}{l}\text { Marmara } \\
\text { Üniversitesi }\end{array}$ & Türkiyat & $\begin{array}{l}\text { Türk Dili ve } \\
\text { Edeb. }\end{array}$ & $\begin{array}{l}\text { Türk Romanı, Değişen Coğ- } \\
\text { rafya, Edebiyat Coğrafyası }\end{array}$ \\
\hline 60. & $\begin{array}{l}\text { Abdülhak Şinasi Hisar'ın roman- } \\
\text { larında mekân-insan ilişkisi }\end{array}$ & Yunus Bilge & $\begin{array}{l}\text { Mehmet } \\
\text { Tekin }\end{array}$ & 2013 & $\mathrm{YL}$ & $\begin{array}{l}\text { Fatih Üni- } \\
\text { versitesi }\end{array}$ & SBE & $\begin{array}{l}\text { Türk Dili ve } \\
\text { Edeb. }\end{array}$ & $\begin{array}{l}\text { Abdülhak Şinasi Hisar, Ro- } \\
\text { man, İnsan, Mekân, Mekân - } \\
\text { İnsan İliş̧kisi }\end{array}$ \\
\hline 61. & $\begin{array}{l}\text { Yeni Türk Edebiyatında Kadıköy } \\
\text { (1872-2000): Hikâye, Roman ve } \\
\text { Anı Kitapları }\end{array}$ & Haluk Öner & $\begin{array}{l}\text { Harun } \\
\text { Duman }\end{array}$ & 2013 & $\mathrm{DR}$ & $\begin{array}{l}\text { Marmara } \\
\text { Üniversitesi }\end{array}$ & Türkiyat & $\begin{array}{l}\text { Türk Dili ve } \\
\text { Edeb. }\end{array}$ & Mekân, Türk Romanı \\
\hline 62. & $\begin{array}{l}\text { Romanda Bir Kent İmgesi Olarak } \\
\text { Ankara: 1920-1955 }\end{array}$ & $\begin{array}{l}\text { Sezin Seda Al- } \\
\text { tun }\end{array}$ & $\begin{array}{l}\text { Ayşe Emel } \\
\text { Kefeli }\end{array}$ & 2013 & $\mathrm{YL}$ & $\begin{array}{l}\text { Marmara } \\
\text { Üniversitesi }\end{array}$ & Türkiyat & $\begin{array}{l}\text { Türk Dili ve } \\
\text { Edeb. }\end{array}$ & $\begin{array}{l}\text { Mekân, Kent, İmge, Başkent, } \\
\text { Ankara, Cumhuriyet Romanı, } \\
\text { Millî Mücadele, Modern- } \\
\text { leşme, Mimarî }\end{array}$ \\
\hline 63. & $\begin{array}{l}\text { Bir Büyük Adam Bir Küçük } \\
\text { Mekân Yahya Kemal Müzesi } \\
\text { Önerisi }\end{array}$ & $\begin{array}{l}\text { Büşra Dilave- } \\
\text { roğlu }\end{array}$ & $\begin{array}{l}\text { İbrahim } \\
\text { Numan }\end{array}$ & 2013 & YL & $\begin{array}{l}\text { Fatih Sultan } \\
\text { Mehmet Va- } \\
\text { kıf Üniver- } \\
\text { sitesi }\end{array}$ & FBE & Mimarlık & $\begin{array}{l}\text { Yahya Kemal, Yahya Kemal } \\
\text { Müzesi, Merzifonlu Kara } \\
\text { Mustafa Paşa Medresesi Sıb- } \\
\text { yan Mektebi, Müze Tasarımı, } \\
\text { Müze Teknolojileri } \\
\end{array}$ \\
\hline 64. & $\begin{array}{l}\text { Orhan Pamuk in The Context of } \\
\text { Istanbul and Authorship: The } \\
\text { Black Book, My Name Is Red, Is- } \\
\text { tanbul }\end{array}$ & Aykun Özgen & Hülya Adak & 2013 & $\mathrm{YL}$ & $\begin{array}{l}\text { Sabancı } \\
\text { Üniversitesi }\end{array}$ & SBE & $\begin{array}{l}\text { Kültürel } \\
\text { Çalış. }\end{array}$ & $\begin{array}{l}\text { Orhan Pamuk, Kara Kitap, } \\
\text { Benim Adım Kırmızı, İstan- } \\
\text { bul: Hatıralar ve Şehir, İstan- } \\
\text { bul, yazarlık }\end{array}$ \\
\hline
\end{tabular}




\begin{tabular}{|c|c|c|c|c|c|c|c|c|c|}
\hline $\begin{array}{l}\mathbf{N} \\
\mathbf{o}\end{array}$ & Tezin Adı & Tezin Yazarı & $\begin{array}{l}\text { Tez } \\
\text { Danışmanı }\end{array}$ & Yil & Tür & Üniversite & Enstitü & $\begin{array}{l}\text { Anabilim } \\
\text { Dalı }\end{array}$ & Anahtar Kelimeler \\
\hline 65. & $\begin{array}{l}\text { Sezai Karakoç Şiirindeki Coğ- } \\
\text { rafya }\end{array}$ & Tuğba Karaca & Fatih And 1 & 2013 & $\mathrm{YL}$ & $\begin{array}{l}\text { Fatih Sultan } \\
\text { Mehmet Va- } \\
\text { kif Üniver- } \\
\text { sitesi }\end{array}$ & SBE & $\begin{array}{l}\text { Türk Dili ve } \\
\text { Edeb. }\end{array}$ & $\begin{array}{l}\text { Sezai Karakoç, Edebiyat Coğ- } \\
\text { rafyası, Coğrafya Merkezli } \\
\text { Okuma }\end{array}$ \\
\hline 66. & $\begin{array}{l}\text { E. M. Forster'ın "Hindistan'a Bir } \\
\text { Geçit" Adlı Romanında Mekân } \\
\text { Temsili Üzerinden Britanyalılar } \\
\text { ile Hintlilerin İlişkilerinin Ana- } \\
\text { lizi }\end{array}$ & $\begin{array}{l}\text { Beyza Demet } \\
\text { Sarıkaya }\end{array}$ & $\begin{array}{l}\text { Mustafa } \\
\text { Ahmet } \\
\text { Süner }\end{array}$ & 2014 & $\mathrm{YL}$ & $\begin{array}{l}\text { Yaşar Üni- } \\
\text { versitesi }\end{array}$ & SBE & $\begin{array}{l}\text { İngiliz Dili } \\
\text { ve Edeb. }\end{array}$ & $\begin{array}{l}\text { Forster, İlişkiler, Arkadaşlık, } \\
\text { Mekân }\end{array}$ \\
\hline 67. & $\begin{array}{l}\text { Jean Echenoz'un Dört Roma- } \\
\text { nında Mekân ve Boşluk: Bir Yil, } \\
\text { Gidiyorum, Koşmak ve } 14\end{array}$ & $\begin{array}{l}\text { Fatma Akbu- } \\
\text { lut }\end{array}$ & $\begin{array}{l}\text { Mehmet } \\
\text { Emin Özcan }\end{array}$ & 2014 & $\mathrm{YL}$ & $\begin{array}{l}\text { Ankara } \\
\text { Üniversitesi }\end{array}$ & SBE & $\begin{array}{l}\text { Fransız Dili } \\
\text { ve Edeb. }\end{array}$ & $\begin{array}{l}\text { Boşluk, JEAN Echenoz, Fran- } \\
\text { sız Edebiyat1, Fransız Ro- } \\
\text { manı, Mekân, Mekânsal Algı, } \\
\text { Monotonluk, Roman, Seyahat }\end{array}$ \\
\hline 68. & $\begin{array}{l}\text { Osmanlı Devleti'nin Kuruluş } \\
\text { Devrini Konu Edinen } \\
\text { larda Moman- }\end{array}$ & $\begin{array}{l}\text { Bünyamin } \\
\text { Çeri }\end{array}$ & $\begin{array}{l}\text { Gülsemin } \\
\text { Hazer }\end{array}$ & 2014 & YL & $\begin{array}{l}\text { Sakarya } \\
\text { Üniversitesi }\end{array}$ & SBE & $\begin{array}{l}\text { Türk Dili ve } \\
\text { Edeb. }\end{array}$ & $\begin{array}{l}\text { Tarihi Roman, Osmanlının } \\
\text { Kuruluşu, Mekân }\end{array}$ \\
\hline 69. & $\begin{array}{l}\text { Ahmet Midhat Efendi'nin Ro- } \\
\text { manlarında Edebiyat Coğrafyası: } \\
\text { Karadeniz ve Çevresi }\end{array}$ & $\begin{array}{l}\text { Serap Aslan } \\
\text { Cobutoğlu }\end{array}$ & $\begin{array}{l}\text { Ayşe Emel } \\
\text { Kefeli }\end{array}$ & 2014 & $\mathrm{DR}$ & $\begin{array}{l}\text { Marmara } \\
\text { Üniversitesi }\end{array}$ & Türkiyat & $\begin{array}{l}\text { Türk Dili ve } \\
\text { Edeb. }\end{array}$ & $\begin{array}{l}\text { Ahmet Midhat Efendi, Edebi- } \\
\text { yat Coğrafyası, Mekân, Coğ- } \\
\text { rafya, Yer, Seyahat, Kafkasya, } \\
\text { Balkanlar, Rusya, Etnik Coğ- } \\
\text { rafya, Siyasî Coğrafya, Kültür } \\
\text { Coğrafyası, Beşerî ve Fizikî } \\
\text { Coğrafya }\end{array}$ \\
\hline 70. & $\begin{array}{l}\text { Türk Romanında Şehirleşme Ol- } \\
\text { gusu }\end{array}$ & $\begin{array}{l}\text { Cem Yilmaz } \\
\text { Budan }\end{array}$ & $\begin{array}{l}\text { Recep } \\
\text { Duymaz }\end{array}$ & 2014 & $\mathrm{DR}$ & $\begin{array}{l}\text { Trakya Üni- } \\
\text { versitesi }\end{array}$ & SBE & $\begin{array}{l}\text { Türk Dili ve } \\
\text { Edeb. }\end{array}$ & $\begin{array}{l}\text { Şehirleşme, Türk Romanı, } \\
\text { Modernleşme, Edebiyat }\end{array}$ \\
\hline 71. & Türk Romanında Konak ve Yalı & Mustafa Dere & Ali Yıldız & 2014 & YL & $\begin{array}{l}\text { Yıldız Tek- } \\
\text { nik Üniver- } \\
\text { sitesi }\end{array}$ & SBE & $\begin{array}{l}\text { Türk Dili ve } \\
\text { Edeb. }\end{array}$ & $\begin{array}{l}\text { Konak, Köşk, Yalı, Türk } \\
\text { Hikâyesi, Mimarî, Medeni- } \\
\text { yet, Osmanlı İmparatorluğu, } \\
\text { Batılılaşma, Çöküş }\end{array}$ \\
\hline
\end{tabular}




\begin{tabular}{|c|c|c|c|c|c|c|c|c|c|}
\hline $\begin{array}{l}\mathbf{N} \\
\mathbf{o}\end{array}$ & Tezin Adı & Tezin Yazarı & $\begin{array}{l}\text { Tez } \\
\text { Danışmanı }\end{array}$ & Yil & Tür & Üniversite & Enstitü & $\begin{array}{l}\text { Anabilim } \\
\text { Dalı }\end{array}$ & Anahtar Kelimeler \\
\hline 72. & $\begin{array}{l}\text { Assia Djebar'ın ve Nedim Gür- } \\
\text { sel'in Yazınında Zaman ve } \\
\text { Mekân Sorunsalı }\end{array}$ & $\begin{array}{l}\text { Cansu Gü- } \\
\text { müştaş Şen }\end{array}$ & $\begin{array}{l}\text { Sidıka Seza } \\
\text { Yılancıoğlu }\end{array}$ & 2014 & YL & $\begin{array}{l}\text { Galatasaray } \\
\text { Üniversitesi }\end{array}$ & SBE & $\begin{array}{l}\text { Karş. Edebi- } \\
\text { yat }\end{array}$ & $\begin{array}{l}\text { Zaman ve Mekân Sorunsall, } \\
\text { Kronotop Teorisi, Mikhail } \\
\text { Bakthin, Metamorfoz, Yol } \\
\text { Kronotopu, Karşıllaşma Kro- } \\
\text { notopu, Eşik Kronotopu, As- } \\
\text { sia Djebar "Medine'den } \\
\text { Uzaklarda", Nedim Gürsel } \\
\text { "Allah'ın Kizları" }\end{array}$ \\
\hline 73. & $\begin{array}{l}\text { Alice Harikalar Diyarı'nda Öy- } \\
\text { küsü: Sinema Uyarlamaları Üze- } \\
\text { rinden Mekânsal Bir Değerlen- } \\
\text { dirme }\end{array}$ & $\begin{array}{l}\text { Çağıl Yurda- } \\
\text { kul }\end{array}$ & Filiz Özer & 2014 & $\mathrm{DR}$ & $\begin{array}{l}\text { İstanbul } \\
\text { Teknik Üni- } \\
\text { versitesi }\end{array}$ & SBE & Sanat Tarihi & $\begin{array}{l}\text { Alice Harikalar Diyarında, Si- } \\
\text { nema, Mekân }\end{array}$ \\
\hline 74. & $\begin{array}{l}\text { Mustafa Kutlu Öykücülüğünde } \\
\text { Mekân: Bir Edebiyat Sosyolojisi } \\
\text { İncelemesi }\end{array}$ & Bilal Can & Fatih Özbay & 2015 & YL & $\begin{array}{l}\text { Dumlupi- } \\
\text { nar Üniver- } \\
\text { sitesi } \\
\end{array}$ & SBE & Sosyoloji & $\begin{array}{l}\text { Mekân, Sosyoloji, Edebiyat } \\
\text { Sosyolojisi, Mekân Sosyolo- } \\
\text { jisi, Köy, Kent }\end{array}$ \\
\hline 75. & $\begin{array}{l}\text { Nezihe Meriç'in Öykülerinde } \\
\text { Kronotop (Zaman-Uzam) }\end{array}$ & $\begin{array}{l}\text { Senem Geze- } \\
\text { roğlu }\end{array}$ & Oktay Yivli & 2015 & YL & $\begin{array}{l}\text { Nevşehir } \\
\text { Hacı Bektaş } \\
\text { Veli Üniver- } \\
\text { sitesi } \\
\end{array}$ & SBE & $\begin{array}{l}\text { Türk Dili ve } \\
\text { Edeb. }\end{array}$ & $\begin{array}{l}\text { Zaman, mekân, kronotop, } \\
\text { Mihail Bahtin, Nezihe Meriç, } \\
\text { öykü }\end{array}$ \\
\hline 76. & $\begin{array}{l}\text { Bir Münevverin Zihin Dünyasi: } \\
\text { Ahmed Midhat Efendi Romanla- } \\
\text { rında Modernleşme Olgusu }\end{array}$ & $\begin{array}{l}\text { Abdullah Öz- } \\
\text { çelik }\end{array}$ & Alev Erkilet & 2015 & YL & $\begin{array}{l}\text { Sakarya } \\
\text { Üniversitesi }\end{array}$ & SBE & $\begin{array}{l}\text { Siyaset ve } \\
\text { SBE }\end{array}$ & $\begin{array}{l}\text { Osmanlı Modernleşmesi, Ah- } \\
\text { med Midhat Efendi ve Ro- } \\
\text { manları, İnsan Tipleri }\end{array}$ \\
\hline 77. & $\begin{array}{l}\text { Edebi Mimarlı̆̆ın İzinde: Virgi- } \\
\text { nia Woolf'un Perde Arası (1941) } \\
\text { Romanındaki Mekânsal Arada } \\
\text { Kalmışlık }\end{array}$ & Seçil Özcan & $\begin{array}{l}\text { Ayşe Sevil } \\
\text { Enginsoy } \\
\text { Ekinci }\end{array}$ & 2015 & YL & $\begin{array}{l}\text { Orta Doğu } \\
\text { Teknik Üni- } \\
\text { versitesi }\end{array}$ & SBE & Mimarlık & $\begin{array}{l}\text { Mekânsal Anlatı, Domesti- } \\
\text { site, Mekânda Mahremiyet ve } \\
\text { Kamusallı, Mekânda Femi- } \\
\text { nenlik ve Maskülenlik, Erken } \\
\text { Yirminci Yüzyıl İngiltere'si }\end{array}$ \\
\hline 78. & $\begin{array}{l}\text { Necati Cumalı'nın Eserlerinde } \\
\text { İzmir ve Çevresi }\end{array}$ & Dilşah Ünlü & $\begin{array}{l}\text { Ertuğrul } \\
\text { Aydın }\end{array}$ & 2015 & YL & $\begin{array}{l}\text { Doğu Akde- } \\
\text { niz Üniver- } \\
\text { sitesi } \\
\end{array}$ & $\begin{array}{l}\text { Lisansüstü } \\
\text { Öğr. Araş. }\end{array}$ & $\begin{array}{l}\text { Türk Dili ve } \\
\text { Edeb. }\end{array}$ & $\begin{array}{l}\text { Necati Cumalı, İzmir, Edebi- } \\
\text { yat, İzmir ve Çevresi, Coğ- } \\
\text { rafya ve Edebiyat }\end{array}$ \\
\hline 79. & $\begin{array}{l}\text { Mimari Anlatının Edebiyattan } \\
\text { Sinemaya Dönüşümü: Temsilin } \\
\text { Değişik Medyalardaki Farklılık- } \\
\text { ları, Devamlılıkları ve Limitleri }\end{array}$ & $\begin{array}{l}\text { Türkan Nihan } \\
\text { Hacıömeroğlu }\end{array}$ & $\begin{array}{l}\text { Celal Abdi } \\
\text { Güzer }\end{array}$ & 2015 & $\mathrm{DR}$ & $\begin{array}{l}\text { Orta Doğu } \\
\text { Teknik Üni- } \\
\text { versitesi }\end{array}$ & FBE & Mimarlık & $\begin{array}{l}\text { Mimari Anlatı, Temsil, Edebi- } \\
\text { yat, Sinema, Mimari Eleştiri, } \\
\text { Kullanım Yoğunluğu, Boris } \\
\text { Vian, Foam of The Daze }\end{array}$ \\
\hline
\end{tabular}




\begin{tabular}{|c|c|c|c|c|c|c|c|c|c|}
\hline $\begin{array}{l}\mathbf{N} \\
\mathbf{o}\end{array}$ & Tezin Adı & Tezin Yazarı & $\begin{array}{l}\text { Tez } \\
\text { Danışmanı }\end{array}$ & Yil & Tür & Üniversite & Enstitü & $\begin{array}{l}\text { Anabilim } \\
\text { Dalı }\end{array}$ & Anahtar Kelimeler \\
\hline 80. & $\begin{array}{l}\text { Metinden Görsele Mimaride Ekf- } \\
\text { rasis }\end{array}$ & $\begin{array}{l}\text { Pelin Melisa } \\
\text { Somer }\end{array}$ & $\begin{array}{l}\text { Arzu } \\
\text { Erdem }\end{array}$ & 2015 & $\mathrm{DR}$ & $\begin{array}{l}\text { İstanbul } \\
\text { Teknik Üni- } \\
\text { versitesi }\end{array}$ & FBE & Mimarlık & Mimari temsil \\
\hline 81. & $\begin{array}{l}\text { Superman Çizgi Romanlarındaki } \\
\text { Tasarım Unsurlarının 1938-2014 } \\
\text { Yıllarındaki Değişimleri }\end{array}$ & $\begin{array}{l}\text { Ekin Can Sey- } \\
\text { han }\end{array}$ & $\begin{array}{l}\text { Umut } \\
\text { Şumnu }\end{array}$ & 2015 & YL & $\begin{array}{l}\text { Başkent } \\
\text { Üniversitesi }\end{array}$ & SBE & $\begin{array}{l}\text { İç Mim. ve } \\
\text { Çevre Tas. }\end{array}$ & $\begin{array}{l}\text { Çizgi Roman, Superman, Mi- } \\
\text { marlık ve Tasarım Tarihi, Su- } \\
\text { perman Tarihi, Çizgi Roman } \\
\text { Tarihi, Superman ve Tasarım }\end{array}$ \\
\hline 82. & $\begin{array}{l}\text { Metafor Aracılı̆̆ıla Kafka'da } \\
\text { Mekân Okumaları }\end{array}$ & Neva Gerçek & $\begin{array}{l}\text { Nilgün } \\
\text { Kuloğlu }\end{array}$ & 2015 & YL & $\begin{array}{l}\text { Karadeniz } \\
\text { Teknik Üni- } \\
\text { versitesi } \\
\end{array}$ & FBE & Mimarlık & $\begin{array}{l}\text { Kafka, Mimarlık, Edebiyat, } \\
\text { Mekân, Metafor }\end{array}$ \\
\hline 83. & $\begin{array}{l}\text { Viktorya ve Yeni-Viktorya Ro- } \\
\text { manında Zaman Mekân İlişkisi }\end{array}$ & $\begin{array}{l}\text { Yasemin Ya- } \\
\text { vaşlar Öza- } \\
\text { kıncı }\end{array}$ & $\begin{array}{l}\text { Dilek } \\
\text { Direnç }\end{array}$ & 2015 & $\mathrm{DR}$ & $\begin{array}{l}\text { Ege Üniver- } \\
\text { sitesi }\end{array}$ & SBE & $\begin{array}{l}\text { İngiliz Dili } \\
\text { ve Edeb. }\end{array}$ & $\begin{array}{l}\text { Charles Dickens, Edebiyat } \\
\text { Postmodernizm, Roman Vik- } \\
\text { torya Dönemi, Zaman Za- } \\
\text { man-Mekân İlişkisi İngiliz } \\
\text { Edebiyatı }\end{array}$ \\
\hline 84. & $\begin{array}{l}\text { Feminist Distopyalarda Mekân } \\
\text { ve Zaman }\end{array}$ & Selçuk Tatar & $\begin{array}{l}\text { Dilek } \\
\text { Direnç }\end{array}$ & 2015 & YL & $\begin{array}{l}\text { Ege } \\
\text { Üniversitesi }\end{array}$ & SBE & $\begin{array}{l}\text { Türk Dili } \\
\text { ve Edeb. }\end{array}$ & $\begin{array}{l}\text { Ütopya, Distopya, Feminist Dis- } \\
\text { topya, Kadın Edebiyatı, Cinsi- } \\
\text { yet, Erendiz Atasü, Marge Pi- } \\
\text { ercy, Doris Lessing, Güneş Say- } \\
\text { gilı'nın Gerçek Yaşamı, Zama- } \\
\text { nın Kıyısındaki Kadın, Hayatta } \\
\text { Kalma Güncesi }\end{array}$ \\
\hline 85. & $\begin{array}{l}\text { Mario Levi'nin Romanlarında } \\
\text { Bellek, Kimlik ve Mekân }\end{array}$ & $\begin{array}{l}\text { Nurkan Dik- } \\
\text { men }\end{array}$ & $\begin{array}{l}\text { Süha } \\
\text { Oğuzertem }\end{array}$ & 2016 & YL & $\begin{array}{l}\text { İstanbul } \\
\text { Bilgi Üni- } \\
\text { versitesi } \\
\end{array}$ & SBE & $\begin{array}{l}\text { Karş. Edebi- } \\
\text { yat }\end{array}$ & $\begin{array}{l}\text { Bireysel Bellek, Toplumsal } \\
\text { Bellek, İstanbul, Mekân }\end{array}$ \\
\hline 86. & $\begin{array}{l}\text { Metin ve Mekân Diyalektiği (Sa- } \\
\text { dık Hidayet'in Kör Bakış Ro- } \\
\text { manı) }\end{array}$ & $\begin{array}{l}\text { Ali Mahdiza- } \\
\text { deh }\end{array}$ & $\begin{array}{l}\text { Aysun } \\
\text { Aydın } \\
\text { Öksüz } \\
\end{array}$ & 2016 & $\mathrm{YL}$ & $\begin{array}{l}\text { Karadeniz } \\
\text { Teknik Üni- } \\
\text { versitesi } \\
\end{array}$ & FBE & Mimarlık & $\begin{array}{l}\text { Mekân, Mimarlık, Edebiyat, } \\
\text { Sadık Hidayet, Kör Baykuş } \\
\text { Romanı }\end{array}$ \\
\hline 87. & $\begin{array}{l}\text { Bir Mekân Olarak Yazı: Kırmızı } \\
\text { Pelerinli Kent ve Romantik Bir } \\
\text { Viyana Yazı'nda Metadiegetik } \\
\text { Anlatılar }\end{array}$ & Zehra Öztürk & $\begin{array}{l}\text { Nur Gürani } \\
\text { Arslan }\end{array}$ & 2017 & YL & $\begin{array}{l}\text { Boğaziçi } \\
\text { Üniversitesi }\end{array}$ & SBE & $\begin{array}{l}\text { Türk Dili ve } \\
\text { Edeb. }\end{array}$ & $\begin{array}{l}\text { Adalet Ağaoğlu, Aslı Erdo- } \\
\text { ğan, Edebiyat, Roman, } \\
\text { Mekân, Üst Söylem, Türk } \\
\text { Edebiyatı }\end{array}$ \\
\hline
\end{tabular}


Mimarlık ve Edebiyat İlişkisine Dair Yapılmış Akademik Çalışmaların Bir Sınıflandırması

\begin{tabular}{|c|c|c|c|c|c|c|c|c|c|}
\hline $\begin{array}{l}\mathbf{N} \\
\mathbf{o}\end{array}$ & Tezin Adı & Tezin Yazarı & $\begin{array}{l}\text { Tez } \\
\text { Danışmanı }\end{array}$ & Yil & Tür & Üniversite & Enstitü & $\begin{array}{l}\text { Anabilim } \\
\text { Dalı }\end{array}$ & Anahtar Kelimeler \\
\hline 88. & $\begin{array}{l}\text { Ahmet Hamdi Tanpınar'ın Şehir } \\
\text { İmgesi ve Beş Şehir Kitabı, İstan- } \\
\text { bul Bölümü Üzerinden İçerik } \\
\text { Analizi Örneği }\end{array}$ & $\begin{array}{l}\text { Ayşe Gökçe } \\
\text { Yücel }\end{array}$ & $\begin{array}{l}\text { Turgay } \\
\text { Kerem } \\
\text { Koramaz }\end{array}$ & 2017 & YL & $\begin{array}{l}\text { İstanbul } \\
\text { Teknik Üni- } \\
\text { versitesi }\end{array}$ & FBE & Mimarlık & $\begin{array}{l}\text { Ahmet Hamdi Tanpınar, İçe- } \\
\text { rik Analizi, Kent Kimliği, } \\
\text { Edebi Eserler, Kentsel Analiz }\end{array}$ \\
\hline 89. & $\begin{array}{l}\text { Nostalji Kentleri: Nostalji, Kara } \\
\text { Kitap ve Bilmemek Romanla- } \\
\text { rında Geçmiş, Gelecek ve Belle- } \\
\text { ğin Mekânda Çakışması }\end{array}$ & $\begin{array}{l}\text { Büşra Çopu- } \\
\text { roğlu }\end{array}$ & $\begin{array}{l}\text { Adriana } \\
\text { Luminita } \\
\text { Raducanu }\end{array}$ & 2017 & YL & $\begin{array}{l}\text { Yeditepe } \\
\text { Üniversitesi }\end{array}$ & SBE & $\begin{array}{l}\text { Karş. Edebi- } \\
\text { yat }\end{array}$ & $\begin{array}{l}\text { Nostalji, Şehir, Bellek, Mekân, } \\
\text { Mircea Cărtărescu, Milan } \\
\text { Kundera, Orhan Pamuk }\end{array}$ \\
\hline 90. & $\begin{array}{l}\text { Mekânın Semiyotiği: Yuri Lot- } \\
\text { man'ın Mekân Teorisinin Farklı } \\
\text { Dönemlere Ait North and South, } \\
\text { Brave New World, ve Oranges } \\
\text { Are Not The Only Fruit Adlı Üç } \\
\text { Roman Üzerinden Eleştirel Ana- } \\
\text { lizi }\end{array}$ & Sena Teber & $\begin{array}{l}\text { Metin } \\
\text { Toprak }\end{array}$ & 2017 & YL & $\begin{array}{l}\text { Kocaeli } \\
\text { Üniversitesi }\end{array}$ & SBE & $\begin{array}{l}\text { İngiliz Dili } \\
\text { ve Edeb. }\end{array}$ & $\begin{array}{l}\text { Yuri Lotman, Yapısalcılık, } \\
\text { Mekân, Semiosphere, Postya- } \\
\text { pısalcılık, Göstergebilim }\end{array}$ \\
\hline 91. & \begin{tabular}{lrr}
\multicolumn{3}{l}{ Masumiyet Müzesinde Yazınsal } \\
Mekânı Henri & Lefebvre'in \\
Mekân & Üçlemesi & Üzerinden \\
Okumak & &
\end{tabular} & Belgin Yuncu & $\begin{array}{l}\text { Aslı Ceylan } \\
\text { Ö. -Zeynep } \\
\text { Tuna Ultav }\end{array}$ & 2017 & YL & $\begin{array}{l}\text { İzmir Eko- } \\
\text { nomi Üni- } \\
\text { versitesi }\end{array}$ & SBE & $\begin{array}{l}\text { Tasarım Ça- } \\
\text { lış. İç Mi- } \\
\text { mari ve } \\
\text { Dek. }\end{array}$ & $\begin{array}{l}\text { Yazınsal Mekân, Henri Lefeb- } \\
\text { vre, Mekân Üçlemesi, Mekân } \\
\text { Temsili, Orhan Pamuk, Ro- } \\
\text { man, Masumiyet Müzesi }\end{array}$ \\
\hline 92. & $\begin{array}{l}\text { Otobiyografik Bellekte Mekânın } \\
\text { Kurulumu ve Mekânsal Durum- } \\
\text { lar: Sinematografik ve Edebi } \\
\text { Üretimler Üzerinden Bir İnce- } \\
\text { leme }\end{array}$ & $\begin{array}{l}\text { Elif Cemre Çe- } \\
\text { likcan }\end{array}$ & $\begin{array}{l}\text { Sidıka Asl1- } \\
\text { han Şenel }\end{array}$ & 2017 & YL & $\begin{array}{l}\text { İstanbul } \\
\text { Teknik Üni- } \\
\text { versitesi }\end{array}$ & FBE & Mimarlık & $\begin{array}{l}\text { Otobiyografik Bellek, Zaman- } \\
\text { Mekân }\end{array}$ \\
\hline 93. & $\begin{array}{l}\text { Kemalettin Kamu'nun Anadolu } \\
\text { Şiirlerinde İnsan ve Mekân Yak- } \\
\text { laşımı }\end{array}$ & $\begin{array}{l}\text { Medine Özas- } \\
\text { lan }\end{array}$ & $\begin{array}{l}\text { Vedi Aşka- } \\
\text { roğlu }\end{array}$ & 2017 & YL & $\begin{array}{l}\text { Ardahan } \\
\text { Üniversitesi }\end{array}$ & SBE & $\begin{array}{l}\text { Türk Dili ve } \\
\text { Edeb. }\end{array}$ & $\begin{array}{l}\text { Kemalettin Kamu'nun Şiirle- } \\
\text { rinde Mekân ve İnsan, Kema- } \\
\text { lettin Kamu'nun Şiirlerinde } \\
\text { Mekân, Mekânın Sosyal ve } \\
\text { Psikolojik Boyutu }\end{array}$ \\
\hline 94. & $\begin{array}{l}\text { Angela Carter ve Edward Ab- } \\
\text { bey'nin Eserlerinde Üçüncü } \\
\text { Alan, Çöl ve Yeniden Varoluş: } \\
\text { Bedenler, Halüsinasyon Yaratan } \\
\text { Mekânlar ve Hayvan/İnsanlar }\end{array}$ & Dilek Çalışkan & $\begin{array}{l}\text { Gillian } \\
\text { Mary Elıza- } \\
\text { beth Alban }\end{array}$ & 2017 & $\mathrm{DR}$ & $\begin{array}{l}\text { İstanbul } \\
\text { Aydın Üni- } \\
\text { versitesi }\end{array}$ & SBE & $\begin{array}{l}\text { İngiliz Dili } \\
\text { ve Edeb. }\end{array}$ & $\begin{array}{l}\text { Üçüncü Alan, Beden, Çöl, } \\
\text { Ekosofi ve Eko-kişilik }\end{array}$ \\
\hline
\end{tabular}




\begin{tabular}{|c|c|c|c|c|c|c|c|c|c|}
\hline $\begin{array}{l}\mathbf{N} \\
\mathbf{o}\end{array}$ & Tezin Adı & Tezin Yazarı & $\begin{array}{l}\text { Tez } \\
\text { Danışmanı }\end{array}$ & Yil & Tür & Üniversite & Enstitü & $\begin{array}{l}\text { Anabilim } \\
\text { Dalı }\end{array}$ & Anahtar Kelimeler \\
\hline 95. & $\begin{array}{l}\text { Son Yirmi Yılın Türk Öyküsünde } \\
\text { Mekânın Kuruluşu }\end{array}$ & Özge Soylu & $\begin{array}{l}\text { Mehmet } \\
\text { Narlı }\end{array}$ & 2017 & YL & $\begin{array}{l}\text { Balıkesir } \\
\text { Üniversitesi }\end{array}$ & SBE & $\begin{array}{l}\text { Türk Dili ve } \\
\text { Edeb. }\end{array}$ & Öykü, Mekân, Kent, Taşra, Ev \\
\hline 96. & $\begin{array}{l}\text { Göçmen Belleğinin Mekânı Kur- } \\
\text { gulama ve Yeniden Üretme Bi- } \\
\text { çimleri: Kolaj, Montaj ve Çeviri }\end{array}$ & $\begin{array}{l}\text { Gamze Oku- } \\
\text { muş }\end{array}$ & Funda Uz & 2017 & YL & $\begin{array}{l}\text { İstanbul } \\
\text { Teknik Üni- } \\
\text { versitesi }\end{array}$ & FBE & Mimarlık & $\begin{array}{l}\text { Göçmen Belleği, Mekân, Ko- } \\
\text { laj, Montaj, Çeviri, Mekânın } \\
\text { Üretimi }\end{array}$ \\
\hline 97. & $\begin{array}{l}\text { Edebiyat, Sinema, Mekân Ara- } \\
\text { sindaki Geçişkenlik Üzerine Bir } \\
\text { Araştırma: Steampunk ve Siber- } \\
\text { punk'ın Farklı Tasarım Sahala- } \\
\text { rındaki İzdüşümleri }\end{array}$ & Başar Sevin & $\begin{array}{l}\text { Özkal Barış } \\
\text { Öztürk }\end{array}$ & 2018 & YL & $\begin{array}{l}\text { Mimar Si- } \\
\text { nan Güzel } \\
\text { Sanatlar } \\
\text { Üniversitesi }\end{array}$ & FBE & Mimarlık & $\begin{array}{l}\text { Bilim kurgu, Steampunk, Si- } \\
\text { berpunk (Cyberpunk), Kur- } \\
\text { gusal Mekân, Gelecek Tasa- } \\
\text { rimları }\end{array}$ \\
\hline 98. & $\begin{array}{l}\text { Konut Mimarisinin Dönüşümü- } \\
\text { nün Kavranışında } \\
\text { Edebiyatın } \\
\text { Araçsallaştırılması: } \\
\text { Yılları Arasında İstanbul Örneği }\end{array}$ & Merve Yilmaz & Şeniz Çıkış & 2018 & YL & $\begin{array}{l}\text { İzmir Yük- } \\
\text { sek Tekno- } \\
\text { loji Üniver- } \\
\text { sitesi }\end{array}$ & FBE & Mimarlık & $\begin{array}{l}\text { Edebiyat ve Mimarlık, Edebi } \\
\text { Mekân, Konut Mimarisi, Ko- } \\
\text { nut Tarihi, Konut Mimarisin- } \\
\text { deki Dönüşüm, Disiplinler } \\
\text { Arası Çalışma }\end{array}$ \\
\hline 99. & $\begin{array}{l}\text { Bir Sinur-Mekân Olarak Anayurt } \\
\text { Oteli ve Zebercet }\end{array}$ & Deniz Çiftçi & $\begin{array}{l}\text { Ferda Kes- } \\
\text { kin }\end{array}$ & 2019 & YL & $\begin{array}{l}\text { İstanbul } \\
\text { Bilgi Üni- } \\
\text { versitesi }\end{array}$ & SBE & $\begin{array}{l}\text { Felsefe ve } \\
\text { Toplumsal } \\
\text { Düşünce }\end{array}$ & $\begin{array}{l}\text { Anayurt Oteli, Otel, Modern } \\
\text { Devlet, Biyo-politika, Çıplak, } \\
\text { Yaşam }\end{array}$ \\
\hline 100. & $\begin{array}{l}\text { Edebiyat ve Modernite İlişkisi: } \\
\text { 20. Yüzyıl Edebi Metinlerinde } \\
\text { "Bahçe Kültürü" Ve Ötekinin } \\
\text { Konumlandırılması }\end{array}$ & Veysel Lidar & $\begin{array}{l}\text { R. Şeyda Ül- } \\
\text { sever }\end{array}$ & 2019 & DR & $\begin{array}{l}\text { Eskişehir } \\
\text { Osmangazi } \\
\text { Üniversitesi }\end{array}$ & SBE & $\begin{array}{l}\text { Karş. Edebi- } \\
\text { yat }\end{array}$ & $\begin{array}{l}\text { Modernite, 'Bahçe Kültürü', } \\
\text { 'Öteki', 'Yabancı', Edebiyat } \\
\text { Sosyolojisi }\end{array}$ \\
\hline 101. & $\begin{array}{l}\text { Mekân/Zaman Bağlamında İvan } \\
\text { Gonçarov'un Romanlarında } \\
\text { Taşra }\end{array}$ & $\begin{array}{l}\text { Natalia Cioba- } \\
\text { nova }\end{array}$ & $\begin{array}{l}\text { Türkan Ol- } \\
\text { cay }\end{array}$ & 2019 & YL & $\begin{array}{l}\text { İstanbul } \\
\text { Üniversitesi }\end{array}$ & SBE & $\begin{array}{l}\text { Slav Dilleri } \\
\text { ve Edeb. }\end{array}$ & $\begin{array}{l}\text { Mekân, Zaman, Taşra, Taşra } \\
\text { karakterleri, Gonçarov, Ola- } \\
\text { ğan Öykü, Oblomov, Yamaç }\end{array}$ \\
\hline 102. & $\begin{array}{l}\text { "Vahşi Ormana Doğru": Orta İn- } \\
\text { gilizce Manzum Arthur Romans- } \\
\text { larında İdeolojik Mekân olarak } \\
\text { Orman }\end{array}$ & $\begin{array}{l}\text { Azime Pekşen } \\
\text { Yakar }\end{array}$ & Burçin Erol & 2019 & DR & $\begin{array}{l}\text { Hacettepe } \\
\text { Üniversitesi }\end{array}$ & SBE & $\begin{array}{l}\text { İngiliz Dili } \\
\text { ve Edeb. }\end{array}$ & $\begin{array}{l}\text { Orta İngilizce Manzum Ro- } \\
\text { mans, Arthur Romansı, Şö- } \\
\text { valyelik Ormanı, Mekânsal } \\
\text { Dönüş, İdeolojik Mekân, Şö- } \\
\text { valyelik Mekânı }\end{array}$ \\
\hline
\end{tabular}


Mimarlık ve Edebiyat İlişkisine Dair Yapılmış Akademik Çalışmaların Bir Sınıflandırması

\begin{tabular}{|c|c|c|c|c|c|c|c|c|c|}
\hline $\begin{array}{l}\mathbf{N} \\
\mathbf{o}\end{array}$ & Tezin Adı & Tezin Yazarı & $\begin{array}{l}\text { Tez } \\
\text { Danışmanı }\end{array}$ & Yil & Tür & Üniversite & Enstitü & $\begin{array}{l}\text { Anabilim } \\
\text { Dalı }\end{array}$ & Anahtar Kelimeler \\
\hline 103. & $\begin{array}{l}\text { Çağdaş Yunan Edebiyatında } \\
\text { Mekân Olarak İstanbul: "Leonis", } \\
\text { "Loksandra" ve "Hacı Manuil" } \\
\text { Romanları }\end{array}$ & $\begin{array}{l}\text { Miouzegien } \\
\text { Pelevan Me- } \\
\text { met }\end{array}$ & $\begin{array}{l}\text { Ferhan Kır- } \\
\text { lidökme } \\
\text { Mollaoğlu }\end{array}$ & 2019 & YL & $\begin{array}{l}\text { Trakya Üni- } \\
\text { versitesi }\end{array}$ & SBE & $\begin{array}{l}\text { Balkan Ça- } \\
\text { lışmaları }\end{array}$ & $\begin{array}{l}\text { İstanbul, Çağdaş Yunan Ede- } \\
\text { biyatı, Mekân, Şehir, Kent } \\
\text { Edebiyatı }\end{array}$ \\
\hline 104. & $\begin{array}{l}\text { A Study of Gothic Space and } \\
\text { Character in The Mysteries Of } \\
\text { Udolpho and Jane Eyre }\end{array}$ & $\begin{array}{l}\text { Anas Waad } \\
\text { Mahgoob }\end{array}$ & Kuğu Tekin & 2019 & YL & $\begin{array}{l}\text { Atılım Üni- } \\
\text { versitesi }\end{array}$ & SBE & $\begin{array}{l}\text { İngiliz Dili } \\
\text { ve Edeb. }\end{array}$ & $\begin{array}{l}\text { A. Radcliffe; C. Bronte; Gotik, } \\
\text { Karakter; Mekân }\end{array}$ \\
\hline 105. & $\begin{array}{l}\text { Ahmet Hamdi Tanpınar Roman- } \\
\text { larında İstanbul'da Gündelik Ha- } \\
\text { yat }\end{array}$ & $\begin{array}{l}\text { Sümeyra Boz- } \\
\text { kurt }\end{array}$ & Fatih And 1 & 2019 & YL & $\begin{array}{l}\text { Fatih Sultan } \\
\text { Mehmet Va- } \\
\text { kuf Üniver- } \\
\text { sitesi } \\
\end{array}$ & SBE & $\begin{array}{l}\text { Türk Dili ve } \\
\text { Edeb. }\end{array}$ & $\begin{array}{l}\text { Tanpınar, Gündelik Hayat, } \\
\text { Edebiyat }\end{array}$ \\
\hline 106. & $\begin{array}{l}\text { Bir Çeviri Nesnesi Olarak Mekân } \\
\text { ve "Biçem Alıştırmaları" Metni } \\
\text { Üzerinden Disiplinlerarası Bir } \\
\text { Çeviri Araştırması }\end{array}$ & Sirma Bilir & Pelin Yıldız & 2019 & $\begin{array}{l}\text { San. } \\
\text { Yet. }\end{array}$ & $\begin{array}{l}\text { Hacettepe } \\
\text { Üniversitesi }\end{array}$ & $\begin{array}{l}\text { Güzel Sa- } \\
\text { natlar }\end{array}$ & $\begin{array}{l}\text { İç Mim. ve } \\
\text { Çevre Tas. }\end{array}$ & $\begin{array}{l}\text { Çeviri, Mekân, Oulipo, } \\
\text { Ouxpo, Ouarchpo, Raymond } \\
\text { Queneau, Exercices de Style, } \\
\text { Biçem Alıştırmaları. }\end{array}$ \\
\hline 107. & $\begin{array}{l}\text { Bilimkurgu Mekânların Anlamı- } \\
\text { nın Belirginleştirilmesinde Med- } \\
\text { yanın Rolü }\end{array}$ & $\begin{array}{l}\text { Hosna Mors- } \\
\text { hedzadeh }\end{array}$ & $\begin{array}{l}\text { Nesip Ömer } \\
\text { Erem }\end{array}$ & 2019 & YL & $\begin{array}{l}\text { İstanbul } \\
\text { Teknik Üni- } \\
\text { versitesi } \\
\end{array}$ & FBE & Mimarlık & $\begin{array}{l}\text { Bilim Kurgu, Mekân, Medya, } \\
\text { Anlatı }\end{array}$ \\
\hline 108. & $\begin{array}{l}\text { Adalet Ağaoğlu'nun Hikâyele- } \\
\text { rinde Mekân }\end{array}$ & Fatma Yıldız & Pelin Ayar & 2019 & YL & $\begin{array}{l}\text { Kocaeli } \\
\text { Üniversitesi }\end{array}$ & SBE & $\begin{array}{l}\text { Türk Dili ve } \\
\text { Edeb. }\end{array}$ & $\begin{array}{l}\text { Adalet Ağaoğlu, Mekân, } \\
\text { Hikâye }\end{array}$ \\
\hline 109. & $\begin{array}{l}\text { Mimarlık Tarihi Yazımında Yön- } \\
\text { temleri: Şevki Balmumcu'nun } \\
\text { Sergi Evi Yapısının Hikâyesinin } \\
\text { "Opera'nın Hayaleti" Grafik Ro- } \\
\text { manı ile Aktarımı }\end{array}$ & $\begin{array}{l}\text { Onur Kutlu- } \\
\text { oğlu }\end{array}$ & $\begin{array}{l}\text { Umut } \\
\text { Şumnu }\end{array}$ & 2019 & YL & $\begin{array}{l}\text { Başkent } \\
\text { Üniversitesi }\end{array}$ & SBE & $\begin{array}{l}\text { İç Mim. ve } \\
\text { Çevre Tas. }\end{array}$ & $\begin{array}{l}\text { Postmodern Tarihyazımı, } \\
\text { Yeni Tarihselcilik, Mimarlık } \\
\text { Tarihyazımı, Şevki Bal- } \\
\text { mumcu, Ankara Sergi Evi, } \\
\text { Ankara Opera Binası, Grafik } \\
\text { Roman }\end{array}$ \\
\hline 110. & $\begin{array}{l}\text { Metinden Diyagrama Mimarlık } \\
\text { Kuramı: Delirious New York ve } \\
\text { Yes is More }\end{array}$ & $\begin{array}{l}\text { F. Zeynep Al- } \\
\text { tınbaşlı }\end{array}$ & Hale Gönül & 2019 & YL & $\begin{array}{l}\text { Mimar Si- } \\
\text { nan Güzel } \\
\text { Sanatlar } \\
\text { Üniversitesi } \\
\end{array}$ & FBE & Mimarlık & $\begin{array}{l}\text { Metin, Diyagram, Mimarlık } \\
\text { Kuramı, Delirious New York, } \\
\text { Yes is More }\end{array}$ \\
\hline 111. & $\begin{array}{l}\text { İstanbul'un "Edebiyat Yaşamı" } \\
\text { Üzerine Etnografik Bir Çalışma }\end{array}$ & $\begin{array}{l}\text { Tülin Sad1- } \\
\text { koğlu }\end{array}$ & $\begin{array}{l}\text { Arif Aca- } \\
\text { loğlu }\end{array}$ & 2019 & DR & $\begin{array}{l}\text { Yeditepe } \\
\text { Üniversitesi }\end{array}$ & SBE & Antropoloji & $\begin{array}{l}\text { Edebiyat Dünyası, Edebiyatın } \\
\text { Merkezleri, Kültür Merkezi } \\
\text { İstanbul, Yazarlar, Edebiyat- } \\
\text { çlar }\end{array}$ \\
\hline
\end{tabular}

idealkent 1761 


\begin{tabular}{|c|c|c|c|c|c|c|c|c|c|}
\hline $\begin{array}{l}\mathbf{N} \\
\mathbf{o}\end{array}$ & Tezin Adı & Tezin Yazarı & $\begin{array}{l}\text { Tez } \\
\text { Danışmanı }\end{array}$ & Yil & Tür & Üniversite & Enstitü & $\begin{array}{l}\text { Anabilim } \\
\text { Dalı }\end{array}$ & Anahtar Kelimeler \\
\hline 112. & $\begin{array}{l}\text { Ayasofya Örneği Üzerinden Mi- } \\
\text { marlıkta Retorik }\end{array}$ & Oktay Orhun & $\begin{array}{l}\text { Bahar Deniz } \\
\text { Çalış Kural }\end{array}$ & 2019 & YL & $\begin{array}{l}\text { İstanbul } \\
\text { Bilgi Üni- } \\
\text { versitesi }\end{array}$ & $\begin{array}{l}\text { Lisansüstü } \\
\text { Programlar }\end{array}$ & Mimarlık & $\begin{array}{l}\text { Ayasofya, Retorik, Edebiyat } \\
\text { Teorisi, Franco Moretti, Mi- } \\
\text { marlık }\end{array}$ \\
\hline 113. & $\begin{array}{l}\text { Kent İmgelerinin Edebi Metin } \\
\text { Üzerinden Araştırılması: Zıkk1- } \\
\text { mın Kökü Romanı Örneği }\end{array}$ & Eda Hallaçeli & $\begin{array}{l}\text { Duygu Sa- } \\
\text { ban }\end{array}$ & 2019 & YL & $\begin{array}{l}\text { Çukurova } \\
\text { Üniversitesi }\end{array}$ & FBE & Mimarlık & $\begin{array}{l}\text { Kent İmgesi, Mimarlık ve } \\
\text { Edebiyat İlişkisi, Zıkkımın } \\
\text { Kökü Romanı, Muzaffer İzgü, } \\
\text { Adana Türkocağı Mahallesi }\end{array}$ \\
\hline 114. & $\begin{array}{l}\text { Lewis Mumford'un Kuramsal } \\
\text { Çalışmaları: Ütopya ve Şehir } \\
\text { Sosyolojisine Katkıları }\end{array}$ & Barış Tekcan & $\begin{array}{l}\text { Köksal Al- } \\
\text { ver }\end{array}$ & 2019 & YL & $\begin{array}{l}\text { İstanbul } \\
\text { Üniversitesi }\end{array}$ & SBE & Sosyoloji & $\begin{array}{l}\text { Lewis Mumford, Kent, } \\
\text { Ütopya, Mezar Şehir, Mitler }\end{array}$ \\
\hline 115. & $\begin{array}{l}\text { Minör Mimarlık İmkanları Üze- } \\
\text { rine Bir Deneme }\end{array}$ & $\begin{array}{l}\text { Ecem Arsla- } \\
\text { nay }\end{array}$ & Can Altay & 2019 & $\mathrm{YL}$ & $\begin{array}{l}\text { İstanbul } \\
\text { Bilgi Üni- } \\
\text { versitesi }\end{array}$ & $\begin{array}{l}\text { Lisansüstü } \\
\text { Programlar }\end{array}$ & Mimarlık & $\begin{array}{l}\text { Minör Mimarlık, Mimarlık } \\
\text { Teorisi, Gündelik Hayat, Sını- } \\
\text { raşımı, Gilles Deleuze }\end{array}$ \\
\hline 116. & $\begin{array}{l}\text { Eleştirel Mimarlık Pratiği Olarak } \\
\text { Plan Çiziminin Poetikası }\end{array}$ & Elif Hant & $\begin{array}{l}\text { Sıdıka Asl1- } \\
\text { han Şenel }\end{array}$ & 2019 & YL & $\begin{array}{l}\text { İstanbul } \\
\text { Teknik Üni- } \\
\text { versitesi }\end{array}$ & FBE & Mimarlık & $\begin{array}{l}\text { Eleştirel Mimarlık, Plan, Çi- } \\
\text { zim, Poetika }\end{array}$ \\
\hline 117. & $\begin{array}{l}\text { Roman mekânı olarak batıl1- } \\
\text { laşma sürecinde istanbul }\end{array}$ & $\begin{array}{l}\text { Hacer Zeynep } \\
\text { Zengin Kartal }\end{array}$ & $\begin{array}{l}\text { Handan } \\
\text { İnci Elçi }\end{array}$ & 2020 & $\mathrm{DR}$ & $\begin{array}{l}\text { Mimar Si- } \\
\text { nan Güzel } \\
\text { Sanatlar } \\
\text { Üniversitesi }\end{array}$ & SBE & $\begin{array}{l}\text { Türk Dili ve } \\
\text { Edeb. }\end{array}$ & $\begin{array}{l}\text { İstanbul, Roman, Mekân, Ba- } \\
\text { tılılaşma, Şehir }\end{array}$ \\
\hline 118. & $\begin{array}{l}\text { Servet-İ Fünûn'da Toplumsal } \\
\text { Mekânn Anlatılar ile Üretimi: } \\
\text { Tahayyüller, İnşalar ve Dene- } \\
\text { yimler Atlası (1891-1910) }\end{array}$ & Gürbey Hiz & $\begin{array}{l}\text { Ayşe Şentü- } \\
\text { rer }\end{array}$ & 2020 & $\mathrm{DR}$ & $\begin{array}{l}\text { İstanbul } \\
\text { Teknik Üni- } \\
\text { versitesi }\end{array}$ & FBE & Mimarlık & $\begin{array}{l}\text { Ahmed Rasim Anlatı, Mekân } \\
\text { Modern, Modern Anlatı, Mo- } \\
\text { dernite, Montaj, Servet-İ Fü- } \\
\text { nun Dergisi, Tevfik Fikret, } \\
\text { Ahmed İhsan Tokgöz }\end{array}$ \\
\hline 119. & $\begin{array}{l}\text { Mimari Temsilde Çevirinin Ya- } \\
\text { ratıcı Boşlukları }\end{array}$ & Başak Eren & $\begin{array}{l}\text { Ayşe Şentü- } \\
\text { rer }\end{array}$ & 2020 & $\mathrm{YL}$ & $\begin{array}{l}\text { İstanbul } \\
\text { Teknik Üni- } \\
\text { versitesi }\end{array}$ & FBE & Mimarlık & $\begin{array}{l}\text { Mimari Temsil, Çeviri, Dilbi- } \\
\text { lim, Yazı }\end{array}$ \\
\hline 120. & $\begin{array}{l}\text { Topoğrafyanın Anlatısı, Anlatı- } \\
\text { nın Topoğrafyası }\end{array}$ & Merve Eflatun & Funda Uz & 2020 & $\mathrm{YL}$ & $\begin{array}{l}\text { İstanbul } \\
\text { Teknik Üni- } \\
\text { versitesi }\end{array}$ & FBE & Mimarlık & $\begin{array}{l}\text { Topoğrafya, Kent, Anlatı, } \\
\text { Edebiyat }\end{array}$ \\
\hline
\end{tabular}




\begin{tabular}{|c|c|c|c|c|c|c|c|c|c|}
\hline $\begin{array}{l}\mathbf{N} \\
\mathbf{o}\end{array}$ & Tezin Adı & Tezin Yazarı & $\begin{array}{l}\text { Tez } \\
\text { Danışmanı }\end{array}$ & Yil & Tür & Üniversite & Enstitü & $\begin{array}{l}\text { Anabilim } \\
\text { Dalı }\end{array}$ & Anahtar Kelimeler \\
\hline 121. & $\begin{array}{l}\text { 1950-1990 Ylları Arasında Bur- } \\
\text { sa'daki Mimarlık ve Planlama } \\
\text { Faaliyetlerinin Yerel Basın Ha- } \\
\text { berleri Üzerinden Değerlendiril- } \\
\text { mesi }\end{array}$ & İmran Satış & Selen Durak & 2020 & YL & $\begin{array}{l}\text { Uludă̆ } \\
\text { Üniversitesi }\end{array}$ & FBE & Mimarlık & $\begin{array}{l}\text { Bursa, Mimarlık, Planlama, } \\
\text { Yerel Basin Haberleri }\end{array}$ \\
\hline 122. & $\begin{array}{l}\text { Mimarlık ve Söylem: Louis } \\
\text { Kahn, Le Corbusier, Turgut Can- } \\
\text { sever ve Öğrencilerle Söyleşiler } \\
\text { Üzerine Bir Çözümleme }\end{array}$ & $\begin{array}{l}\text { Sümeyye Y1l- } \\
d_{11 z}\end{array}$ & $\begin{array}{l}\text { Mehmet İn- } \\
\text { ceoğlu }\end{array}$ & 2020 & YL & $\begin{array}{l}\text { Anadolu } \\
\text { Üniversitesi }\end{array}$ & FBE & Mimarlık & $\begin{array}{l}\text { Mimarlık, Söylem, Söyleşiler, } \\
\text { Turgut Cansever, Le Corbu- } \\
\text { sier, Louis I. Kahn }\end{array}$ \\
\hline 123. & $\begin{array}{l}\text { Mijabad, Labirenta Cinan ve Ge- } \\
\text { rineka Guernicaye Örnekleriyle } \\
\text { Kürtçe (Kurmanci) Romanında } \\
\text { Mekân Algısı }\end{array}$ & Cihan Kaynar & Ayhan Tek & 2020 & YL & $\begin{array}{l}\text { Muş Al- } \\
\text { parslan } \\
\text { Üniversitesi }\end{array}$ & SBE & $\begin{array}{l}\text { Kürt Dili ve } \\
\text { Kültürü }\end{array}$ & $\begin{array}{l}\text { Mekân, Yer, Roman, Kahra- } \\
\text { man, Olay Örgüsü, Kürtçe } \\
\text { Roman }\end{array}$ \\
\hline 124. & $\begin{array}{l}\text { Bir Kaçış Ütopyasının Mekanları: } \\
\text { Servet-i Fünun'un Yeşil Yurt Ha- } \\
\text { yaline Dair Bir Araştırma }\end{array}$ & $\begin{array}{l}\text { Gönenç Kurpı- } \\
\text { nar }\end{array}$ & $\begin{array}{l}\text { Mustafa Ha- } \\
\text { luk Zelef }\end{array}$ & 2020 & YL & $\begin{array}{l}\text { Orta Doğu } \\
\text { Teknik Üni- } \\
\text { versitesi } \\
\end{array}$ & FBE & Mimarlık & $\begin{array}{l}\text { Kaçış Ütopyaları, Türk Ütop- } \\
\text { yaları, Edebi Mekânlar, Yeşil } \\
\text { Yurt, Servet-i Fünun }\end{array}$ \\
\hline 125. & $\begin{array}{l}\text { Leyla Hanım ve Şeref Hanım Di- } \\
\text { vanlarında Zaman ve Mekân } \\
\text { Kavramları Üzerine İnceleme }\end{array}$ & Sibel Ökmen & $\begin{array}{l}\text { Ayşe Çele- } \\
\text { bioğlu }\end{array}$ & 2020 & YL & $\begin{array}{l}\text { Artvin Ço- } \\
\text { ruh Üniver- } \\
\text { sitesi }\end{array}$ & $\begin{array}{l}\text { Lisansüstü } \\
\text { Eğitim }\end{array}$ & $\begin{array}{l}\text { Türk Dili ve } \\
\text { Edeb. }\end{array}$ & $\begin{array}{l}\text { Klasik Türk Edebiyat1, } \\
\text { Mekân, Zaman, Leylâ Hanım, } \\
\text { Şeref Hanım }\end{array}$ \\
\hline
\end{tabular}

